\title{
Innate immunity and monocyte-macrophage activation in atherosclerosis
}

\author{
Joseph Shalhoub ${ }^{1,2}$, Mika A Falck-Hansen ${ }^{1}$, Alun H Davies² and Claudia Monaco ${ }^{1 *}$
}

\begin{abstract}
Innate inflammation is a hallmark of both experimental and human atherosclerosis. The predominant innate immune cell in the atherosclerotic plaque is the monocyte-macrophage. The behaviour of this cell type within the plaque is heterogeneous and depends on the recruitment of diverse monocyte subsets. Furthermore, the plaque microenvironment offers polarisation and activation signals which impact on phenotype. Microenvironmental signals are sensed through pattern recognition receptors, including toll-like and NOD-like receptors thus dictating macrophage behaviour and outcome in atherosclerosis. Recently cholesterol crystals and modified lipoproteins have been recognised as able to directly engage these pattern recognition receptors. The convergent role of such pathways in terms of macrophage activation is discussed in this review.
\end{abstract}

Keywords: Atherosclerosis Inflammation, Innate immunity, Toll-like receptors, Monocyte subsets, Macrophage subtypes, Macrophage polarisation

\section{Introduction}

Atherothrombotic vascular disease is quickly becoming the leading cause of mortality worldwide, accounting for a fifth of all deaths [1]. The manifestations of the disease are often sudden and dramatic, including myocardial infarction and sudden death. Cerebrovascular atherothrombosis is responsible for ischaemic stroke, a major source of disability and dependence, and represents a rising health-economic burden [2].

Progress has been made in refining our understanding of the process of inflammation which underlies atherosclerosis since the early descriptions by Rudolf Virchow during the $19^{\text {th }}$ century $[3,4]$ and subsequently Russell Ross in the late 1990s [5-8]. The development of an atherosclerotic plaque begins with the recruitment of blood-borne inflammatory cells at sites of lipid deposition [9] or arterial injury [5]. Local rheological factors, such as low and oscillatory (with vortices) blood-to-wall shear stress dictate the location of atherosclerotic plaques to characteristic points along the vasculature $[10,11]$.

\footnotetext{
* Correspondence: c.monaco@imperial.ac.uk

${ }^{1}$ Cytokine Biology of Atherosclerosis, Kennedy Institute of Rheumatology,

Faculty of Medicine, Imperial College London, UK

Full list of author information is available at the end of the article
}

Atherosclerosis shares features with diseases caused by chronic inflammation [7]. Inflammation is intrinsically linked with disease activity, as the numbers of monocyte-macrophages infiltrating the plaque [12] and their location at plaque rupture-sensitive sites (such as the fibrous cap and areas of erosion $[13,14]$ ) is related to plaque vulnerability. Moreover, lymphocyte abundance and their activation markers relate to plaque activity [13]. Macrophage differentiation is acknowledged as critical for the development of atherosclerosis [15]. The intimate relationship between atherosclerosis and inflammation is further exemplified by the involvement of cytokines and chemokines at all stages of the process of atherosclerosis (reviewed in detail by [16]). The extent of the inflammatory infiltrates and their strategic location within the protective fibrous cap is associated with plaque rupture and/or thrombosis [17]. Adventitial inflammation has also been described [18], and is linked with an expansion of the adventitial vasa vasorum in unstable atherosclerosis [19]. The inflammatory nature of atherosclerosis is supported by the association between circulating plasma inflammatory markers, particularly C-reactive protein, with cardiovascular outcomes, even in the absence of dyslipidaemia [6]. Further evidence for a link between systemic inflammation and cardiovascular disease is the increased 
incidence of cardiovascular events in chronic inflammatory conditions, such as inflammatory arthritis and systemic lupus erythematosus $[7,8]$. The expanding knowledge base regarding inflammation in atherosclerosis has resulted in a keen interest in targeted therapeutics and functional imaging tools for the high-risk atherosclerotic plaque [20].

\section{Innate immunity is a key player in atherosclerosis}

How is inflammation established and maintained within an atherosclerotic plaque? Inflammation in physiological conditions is a self-limiting ancient protective mechanism that defends the host from invading pathogens. It relies on two arms: innate immunity and adaptive immunity. Innate immunity is activated immediately upon encounter with the pathogen and is executed primarily by myeloid cells with the participation of some "innate" lymphocyte sub-populations. Adaptive immunity is a second line of defence that is based upon the generation of antigen-specific recognition apparatus at cellular ( $\mathrm{T}$ cell receptor) and humoral (antibody) levels.

In the past decade it has become apparent that the innate arm of the immune inflammatory response is not merely a concoction of non-specific responses and phagocytosis. Rather it is the main orchestrator of the subsequent adaptive responses and is able to sense pathogen associated molecular patterns (PAMPs) with a specificity which was previously unsuspected. In inflammatory conditions, including atherosclerosis, the immune inflammatory apparatus is chronically activated, either due to the persistence of pro-inflammatory stimuli or due to the failure of regulatory mechanisms that should facilitate resolution. Significant progress has been made in the field linking innate immune sensors to the recognition of cholesterol [21] and modified lipoproteins [22-24]. Thus diverse innate immune signalling pathways have been seen to cooperate to induce and maintain inflammation upon exposure to exogenous and, importantly, endogenous molecular patterns [21,25].

The most abundant cell types within the atherosclerotic plaque are innate immune cells, such as monocytemacrophages, dendritic cells (DCs) and mast cells. Monocytes-macrophages came to the forefront of research owing to new awareness that they may represent a more heterogeneous and phenotypically plastic population than previously anticipated. In this review we focus on the role of macrophage activation and phenotypic polarisation in lesion formation and vulnerability.

\section{Macrophage heterogeneity in atherosclerosis}

Macrophages are a heterogeneous population of cells that adapt in response to a variety of micro-environmental signals; their phenotype is very much a function of environmental cues [26,27]. In a nomenclature mirroring Th1 and Th2 polarisation, macrophages are usually defined as M1 or M2 [28]. Classically activated (M1) macrophages were the first to be defined $[29,30]$ as pro-inflammatory. Alternatively activated (M2) macrophages have been originally characterised in the context of Th2-type immune responses [29]. Subsets of M2-like macrophages have been later found to contribute to wound healing and regulation of inflammatory processes [31]. Characteristic cytokine and chemokine signatures pertaining to human monocyte-to-macrophage differentiation and M1/M2 macrophage polarisation (Table 1) have been described [28,32].

Macrophage phenotypic polarisation may have a role in the fate of an atherosclerotic plaque. The plaque is an environment with a strong skew towards Th1 lymphocytic responses, resulting in high levels of IFN $\gamma[33,34]$ which could in theory privilege M1-type macrophage polarisation. However, studies thus far have demonstrated macrophage heterogeneity within atherosclerosis, supporting that both M1 and M2 macrophages are present in human and murine atherosclerotic lesions. In an $\mathrm{ApoE}^{-/-}$murine model of atherosclerosis, early lesions were seen to be infiltrated by M2 (arginase $\mathrm{I}^{+}$) macrophages [35]. As lesions progressed a phenotypic switch was observed, with an eventual predominance of M1 (arginase $\mathrm{II}^{+}$) macrophages. Upon exposure to the oxidised phospholipid 1-palmitoyl-2-arachidonoyl-sn-3phosphorylcholine (oxPAPC), murine macrophages adopted a previously undescribed phenotype (Figure 1) [36]. A reduction in the expression of genes characteristic of both M1 and M2, coupled with an up-regulation of a unique redox gene signature that includes haemoxygenase 1, was observed. This population, termed Mox macrophages, are nuclear factor erythroid 2-like 2 (Nrf2)-dependent and have been shown to comprise approximately $30 \%$ of all macrophages in advanced atherosclerotic lesions of $\mathrm{LDLR}^{-/-}$mice [36]. A variety of subtypes have been described which are considered to fall under the umbrella of alternatively activated M2 macrophages (reviewed in [31,37]). An example of this occurs with administration of IL33 (which is functionally atheroprotective [38]) to genetically obese diabetic (ob/ $o b)$ mice, resulting in increased production of Th2 cytokines and polarisation of adipose tissue macrophages to a CD206 ${ }^{+}$M2 phenotype [39].

In human lesions different macrophage phenotypes exist, and do so in different plaque locations. M2 (CD68 ${ }^{+} \mathrm{CD}_{206^{+}}$) macrophages were seen to reside in areas more stable zones of the plaque distant from the lipid core, with their M1 $\left(\mathrm{CD} 68^{+} \mathrm{CCL} 2^{+}\right)$counterparts displaying a distinct tissue localisation pattern [40]. Subsequent work has confirmed this, finding $\mathrm{CD}^{+} 8^{+} \mathrm{CD}^{206}{ }^{+}$ cells far from the lipid core [41]. CD $68^{+}$CD206 ${ }^{+}$macrophages were also seen to contain smaller lipid droplets 
Table 1 Cytokine and chemokine genes, and those of receptors (in italics), known to be differentially transcribed in human M1 and M2 macrophage in vitro polarisation (Adapted from [28] and [27])

\begin{tabular}{|c|c|}
\hline $\mathrm{M} 1>\mathrm{M} 2$ & $\mathrm{M} 2>\mathrm{M} 1$ \\
\hline CXCL11 & Insulin-like growth factor 1 \\
\hline CCL19 & CCL23 \\
\hline CXCL10 & CCL18 \\
\hline Tumour necrosis factor ligand superfamily, member 2 & CCL13 \\
\hline CCL15 & Bone morphogenic protein 2 \\
\hline Interleukin 12B & Hepatocyte growth factor \\
\hline Interleukin 15 & Fibroblast growth factor 13 \\
\hline Tumour necrosis factor ligand superfamily, member 10 & CXCL1 \\
\hline Interleukin 6 & Transforming growth factor $\beta$ receptor I \\
\hline CCL20 & CXCR4 \\
\hline Visfatin & Mannose receptor C type 1 (CD206) \\
\hline \multicolumn{2}{|l|}{ Endothelial cell growth factor } \\
\hline \multicolumn{2}{|l|}{ CCL1 } \\
\hline \multicolumn{2}{|l|}{ CCL17 } \\
\hline \multicolumn{2}{|l|}{ CCL22 } \\
\hline \multicolumn{2}{|l|}{ CCL13 } \\
\hline \multicolumn{2}{|l|}{ Transforming growth factor $\beta 2$} \\
\hline \multicolumn{2}{|l|}{$C C R 7$} \\
\hline \multicolumn{2}{|l|}{ Interleukin 2 receptor $\alpha$ chain } \\
\hline \multicolumn{2}{|l|}{ Interleukin 15 receptor $\alpha$ chain } \\
\hline Interleukin 7 receptor & \\
\hline
\end{tabular}

CCL2 was upregulated in M-CSF differentiated macrophages in one study [27], whilst relatively increased by GM-CSF in another [28].

compared to $\mathrm{CD}^{+} 8^{+} \mathrm{CD}^{206^{-}}[41]$. A subset of M2 macrophages has recently been detected in association with intraplaque haemorrhage in coronary atheromata [42]. These macrophages express high levels of CD163 (a scavenger receptor that binds to haemoglobin-haptoglobin ( $\mathrm{HbHp}$ ) complexes). They also express low levels of MHC Class II and display low release of the reactive oxidative species hydrogen peroxide. Expression of CD163 by peripheral blood monocytes was not shown to be different between the $\mathrm{CD} 14^{+} \mathrm{CD} 16^{+}$and $\mathrm{CD} 14^{++}$ CD16 subsets. However, when monocytes were differentiated into macrophages in the presence of $\mathrm{HbHp}$ complexes for 8 days, they matured into a CD163 ${ }^{\text {high }}$ HLA-DR ${ }^{\text {low }}$ phenotype similar to the haemorrhage-associated macrophages within coronary plaques [42]. Differentiation into this macrophage subtype was dependent on the expression of CD163 and IL10 during in vitro blockade experiments. Interestingly, this polarisation was prevented by the incubation with specific inhibitors of endolysosomal acidification, such as chloroquine which is known to interfere with endosomal TLR signalling [42].

Lesion development and stability are not only determined by the influx and differentiation of inflammatory cell subsets, but also their ability to act on vascular extracellular matrix. Importantly, the macrophage subtypes display a differential expression of matrix metalloproteinase (MMP) and tissue inhibitor of metalloproteinase (TIMP) [43]. In particular, a subset of lesional foam cell macrophages characterised by a high expression of MMP14 (membrane type $1 \mathrm{MMP}$ ) and a low expression of TIMP3 were highly invasive and catabolic [44]. Moreover, such expression pattern of MMP14 and TIMP 3 was associated with markers of M1 polarisation [44], whilst expression of MMP12 was associated with an M2-typical down-regulation of arginase I [45]. Thus MMP expression by macrophage subsets is also heterogeneous, further highlighting the different functionalities of these cells.

The heterogeneity of macrophage phenotypes in the various studies is an important feature of our current view of atherosclerosis. Studies assessing multiple markers in human and murine lesions are needed to map such degree of heterogeneity. How is such heterogeneity generated? It is likely to be the result of recruitment of different monocytes subsets, or stimuli provided by the plaque microenvironment. Gordon and Martinez have proposed a four-stage paradigm of macrophage activation, where differentiation through exposure to growth factors is the first stage [46]. This stage is followed by priming (through cytokines, particularly IFN $\gamma$ and IL4), activation (by TLR or similar), and finally resolution and repair (mediated by IL10, transforming growth factor (TGF)- $\beta$, nucleotides, glucocorticoids or lipotoxins) [46]. 


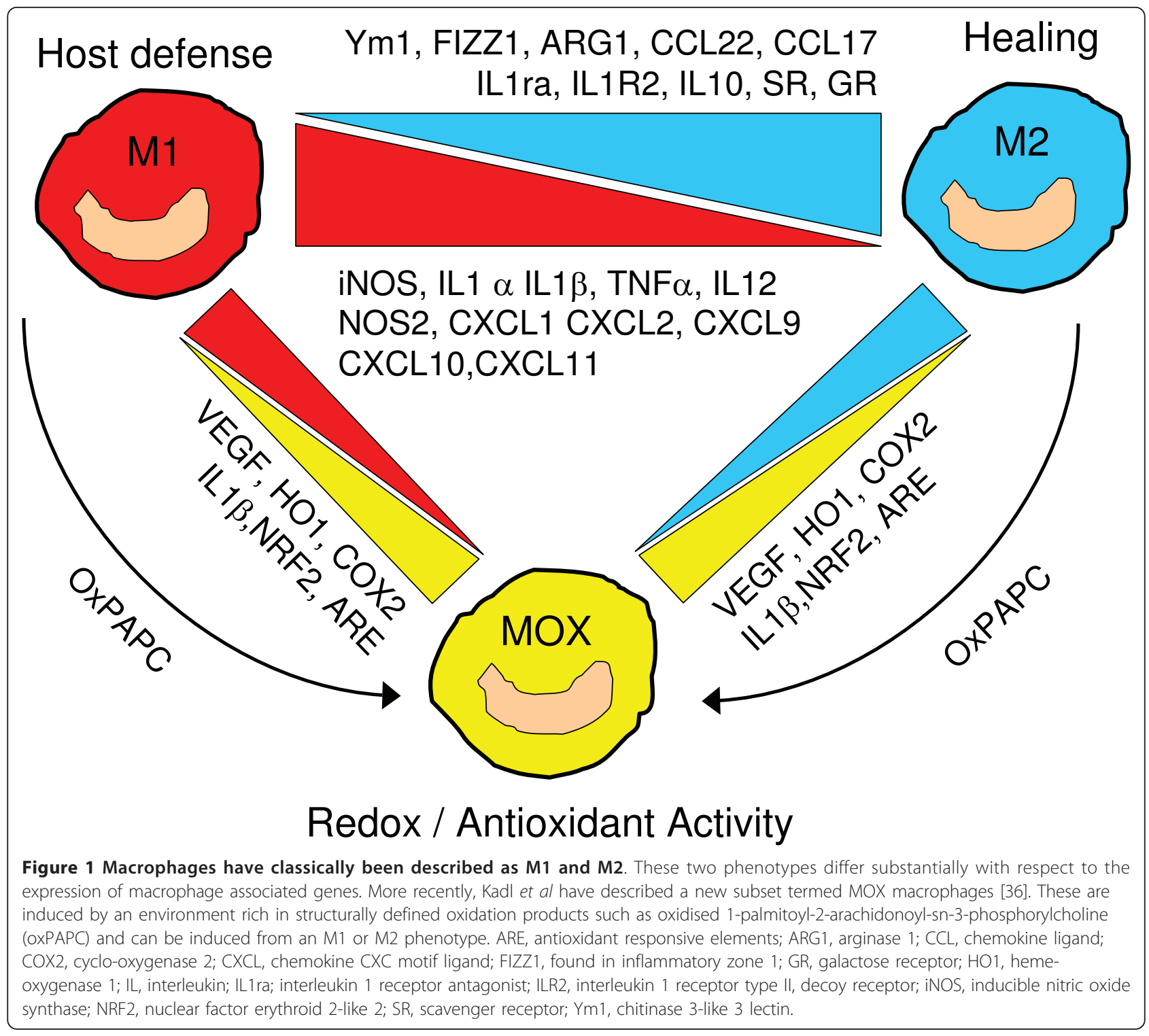

This review will explore the potential mechanisms leading to macrophage activation and polarisation in atherosclerosis.

\section{Recruitment of monocyte subsets to atherosclerotic plaques}

In both mice and humans, monocytes comprise 5 to $10 \%$ of peripheral blood leukocytes [25]. Two major circulating monocyte subsets have been described in humans and mice alike, the distinction made on the basis of size, granularity, and the differential expression of chemokine receptors and adhesion molecules [47]. The two mouse monocyte sub-populations are represented approximately equally in murine blood; they are distinguished based upon their expression of CCR2, $\mathrm{CX}_{3} \mathrm{CR} 1$ and Ly6C [48]) [49]. CCR2 ${ }^{+} \mathrm{CX}_{3} \mathrm{CR} 1^{\text {low }} \mathrm{Ly} 6 \mathrm{C}^{+}$ monocytes are termed 'inflammatory' monocytes, and $\mathrm{CCR}^{-} \mathrm{CX}_{3} \mathrm{CR} 1^{\text {high }} \mathrm{Ly} 6 \mathrm{C}^{-}$are referred to as 'resident' monocytes $[31,47,50]$.

Similarly to mouse monocytes, human monocytes can be separated into two groups based upon cell surface CD14 - a toll-like receptor (TLR) co-receptor sensing exogenous molecular patterns such as lipopolysaccharide (LPS) - and CD16 - a member of the family of Fc (Fragment, crystallisable) receptors Fc $\gamma$ RIII. In humans, about 90\% of monocytes are CD14.+ ${ }^{++}$D 16 ' and termed 'classical' monocytes $[50,51]$. CD $14^{+} \mathrm{CD} 16^{+}$monocytes, which constitute the remaining minority, are referred to as 'non-classical' [52-55] (Table 2).

To date, monocyte phenotype data has centred largely on the murine system [29]. Similarities between mice and humans may be accounted for, at least in part, by 
Table 2 A comparison of human and murine monocyte subsets, highlighting differences in surface receptor phenotypes

\begin{tabular}{|c|c|c|}
\hline & Human & Mouse \\
\hline Classical/Inflammatory & $\begin{array}{c}\mathrm{CD}^{+} 4^{++} \text {CD16 }[195,196] \\
(>90 \%)\end{array}$ & Ly6C $^{+} \mathrm{CCR}^{+} \mathrm{CD} 62 \mathrm{~L}^{+} \mathrm{CX}_{3} \mathrm{CR} 1^{\text {low }}[47,59]$ ( 50\%) \\
\hline Non-Classical/Resident & $\begin{array}{c}\mathrm{CD} 4^{+} \mathrm{CD}^{\mathrm{C}} 6^{+}[195,196] \\
(<10 \%)\end{array}$ & Ly6C CCR2- CD62L- CX ${ }_{3}$ CR1 high $[47,59]$ ( 50\%) \\
\hline
\end{tabular}

The approximate abundance in peripheral blood is shown in brackets, however this may not reflect the proportions in other sites such as the spleen.

the expression of surface receptors. For instance, chemokine receptors CCR1 and CCR2 are highly expressed on both $\mathrm{CD}_{16}^{-}$human and $\mathrm{Ly}_{6 \mathrm{C}^{+}}$murine monocytes, and $\mathrm{CX}_{3} \mathrm{CR} 1$ is increased on $\mathrm{CD}^{+} 6^{+}$human and $\mathrm{Ly}_{6} \mathrm{C}^{-}$ mouse monocytes [47,56,57] (reviewed in [58]). More than 130 of these gene expression differences were conserved between mouse and human monocyte subsets, with many of these differences also confirmed at the protein level [59]. A notable difference among these was the high expression of peroxisome proliferator-activated receptor $\gamma$ (PPAR $\gamma$, discussed in greater detail below) in Ly6 $\mathrm{C}^{-}$mouse monocytes, but not the proposed $\mathrm{CD} 16^{+}$ counterpart [59]. As such, the differences between mouse and human monocyte subsets may be greater than had been expected and may be difficult to reconcile.

Two groups independently reported in 2007 that the Ly $6 \mathrm{C}^{+}$inflammatory monocyte subset increases its representation dramatically in the peripheral blood of the hypercholesterolemic apolipoprotein E (ApoE) deficient mouse on a high-fat diet $[56,60]$. Conversely, hypercholesterolemia did not affect $\mathrm{Ly}^{-} \mathrm{C}^{-}$monocytes and also discouraged the conversion of $\mathrm{Ly} 6 \mathrm{C}^{+}$into Ly6 $\mathrm{C}^{-}$monocytes. Other mechanisms proposed for this increase in $\mathrm{Ly}_{6 \mathrm{C}} \mathrm{C}^{+}$monocytes during hypercholesterolemia include increased proliferation and reduced apoptosis [61]. Ly6C $\mathrm{C}^{+}$monocytes are recruited to activated endothelium and are thought to represent the majority of infiltrating macrophages within atherosclerotic plaques [60]. Conversely, Ly6 $\mathrm{C}^{-}$enter the atherosclerotic plaque in lower numbers and preferentially express CD11c upon entry [56]. This differential recruitment based upon Ly6C expression may condition the macrophage phenotype within the plaque, with reports that Ly6C $\mathrm{C}^{+}$monocytes differentiate into cells that resemble M1 macrophages and that cells derived from Ly6C monocytes exhibit M2 characteristics [62-65].

Chemokine receptors are necessary for monocytes to traverse the endothelium [56,66] (reviewed in [16]). $\mathrm{CX}_{3} \mathrm{CR}^{-/-}$(fractalkine receptor) $[67,68], \mathrm{CX}_{3} \mathrm{CL}^{-/-}$ (fractalkine) [69] and CCR2 $2^{-/-}[70,71]$ mice (in the context of low density lipoprotein receptor (LDLR) or ApoE deficiency) exhibited a reduction in - but not elimination of - atherosclerosis. Furthermore, deficiency of CCR5 (the receptor for CCL5, a chemokine also known as RANTES) in $\mathrm{ApoE}^{-/-}$mice does not appear to be protective in the early stages of atherosclerosis [72]. Subsequently, in a wire injury study also using the $\mathrm{ApoE}^{-/-}$ mouse model, the authors found a significant reduction in the area neo-intima formation with concurrent CCR5 deficiency, but not with concurrent absence of the alternative CCL5 receptor CCR1 [73]. More recently, a multiple knockout model has reaffirmed the thinking that CCL2 (MCP1), CCR5 and $\mathrm{CX}_{3} \mathrm{CR} 1$ play independent and additive roles in atherogenesis [74]. Combined inhibition of CCL2, CCR5 and $\mathrm{CX}_{3} \mathrm{CR} 1$ in $\mathrm{ApoE}^{-/-}$mice results in a $90 \%$ reduction in atherosclerosis, which is related to progressive monocytopaenia $[66,74]$. However, chemokine receptor utilisation during recruitment to atherosclerotic plaques differentiates $\mathrm{Ly}_{6 \mathrm{C}} \mathrm{C}^{+}$and $\mathrm{Ly}_{6 \mathrm{C}}$ monocytes. Ly6 $\mathrm{C}^{+}$monocytes are recruited to mouse atherosclerosis via CCR2, CCR5 and $\mathrm{CX}_{3} \mathrm{CR} 1$ [61]. Conversely, Ly6 $\mathrm{C}^{-}$monocytes are recruited less frequently and through CCR5.

In human atherosclerosis, patients with coronary artery disease have increased numbers of circulating CD $14^{+} \mathrm{CD}_{16}{ }^{+}$monocytes compared to controls [75]. Furthermore, these patients have raised levels of serum TNF $\alpha$ [76]. There is, however, data to the contrary with the finding that inflammatory genes and surface markers were down-regulated in monocytes of patients with coronary atherosclerosis [77]. Of relevance, CD14 ${ }^{+} \mathrm{CD} 16^{+}$ monocytes have also been shown to exhibit pro-inflammatory and pro-atherosclerotic activity in a population of elderly human subjects. These activated monocytes exhibited increased interaction with endothelium and had higher expression of chemokine receptors [78]. Other studies have suggested that the bone marrow is the source of these monocytes $[79,80]$.

\section{Macrophage differentiation in atherosclerosis}

Early work relating to the effect of the colony stimulating factors (CSFs) on macrophage phenotype was undertaken by Hamilton and colleagues [81,82]. A variety of groups have generated data using monocytes differentiated in vitro, via exposure to either M-CSF or GMCSF $[82,83]$. In vitro differentiation with M-CSF results in a macrophage phenotype close to that of M2 [28]. GM-CSF plays a role in the induction of a pro-inflammatory macrophage phenotype that resembles M1 
polarisation, proficiently producing inflammatory cytokines such as TNF $\alpha$ and IL6, and being involved in tissue destruction [28].

In further murine studies, both M-CSF and GM-CSF have been shown to be important in plaque development. Smith et al studied ApoE ${ }^{-1-}$ mice crossbred with the osteopetrotic mutation of the M-CSF gene. These mice were fed a low-fat chow diet with the double mutants exhibiting significantly smaller proximal aortic lesions, at an earlier stage of progression and with fewer macrophages as compared with their control $\mathrm{ApoE}^{-/-}$littermates [84]. The production of GM-CSF from smooth muscle cells leads to the activation of monocytes during atherogenesis [85]. In another study using the hypercholesterolaemic ApoE $\mathrm{E}^{-/-}$mouse, animals on a high-fat diet were injected with doses of $10 \mu \mathrm{g} / \mathrm{kg}$ GM-CSF or G-CSF daily for 5 days on alternating weeks for a total of 20 doses during an 8 week period, finding that both G-CSF and GM-CSF treatment resulted in increased atherosclerotic lesion extent [86]. LDLR-null mice have been employed in a study which combined 5-bromo-2'-deoxyuridine pulse labelling with en face immunoconfocal microscopy to demonstrate that systemic injection of GM-CSF markedly increased intimal cell proliferation, whilst functional GM-CSF blockade inhibited proliferation [87].

In a key study, Waldo and colleagues examined human macrophages differentiated in vitro for 7 days with either M-CSF or GM-CSF [27]. They characterised gene expression, surface phenotype, cytokine production and lipid handling in these two macrophage groups. With regards to gene expression, they demonstrated differential expression of genes of inflammation (Table 1) and cholesterol homeostasis between the two groups, including that GMCSF macrophages exhibited a ten-fold increased gene expression of PPAR $\gamma$. M-CSF differentiated macrophages spontaneously accumulated cholesterol when incubated with unmodified low density lipoprotein (LDL), whilst GM-CSF differentiated macrophages took up similar levels only when exposed to protein kinase C. Macrophages differentiated with M-CSF were shown by immunofluoresence to express CD14 $\left(\mathrm{CD}^{+} 8^{+} \mathrm{CD} 14^{+}\right)$, whilst GM-CSF differentiated macrophages were $\mathrm{CD} 8^{+} \mathrm{CD} 14^{-}$. Interestingly, human coronary plaque samples were shown to contain predominantly $\mathrm{CD}^{+} 8^{+} \mathrm{CD} 14^{+}$[27].

\section{Priming of macrophages in the atherosclerotic plaque}

Macrophages are M1-primed by exposure to interferon (IFN) $-\gamma$ [37]. The key role of IFN $\gamma$ [88] has been confirmed in experimental atherosclerosis whereby $\mathrm{ApoE}^{-/-}$ IFN $\gamma$ receptor $^{-/-}$mice displayed a substantial reduction in lesion size compared to $\mathrm{ApoE}^{-/-}$[89]. This reduction was manifest alongside a reduced level of macrophages and $\mathrm{T}$ lymphocytes within the lesions. Furthermore, murine cardiac allografts sited in IFN $\gamma^{-1-}$ recipients had reduced transplant atherosclerosis [90].

Alternative M2 polarisation has originally been described as the result of exposure to interleukin (IL4) $[28,40,58,91]$. M2 macrophages have a notable role in catabasis, the process inflammation resolution which when fails results in progression of atherosclerosis [92].

Wound healing macrophages, concerned primarily with tissue repair, are similar to the alternatively activated (M2) macrophages which have been described above. Wound healing macrophages establish their phenotype upon exposure to IL4 and/or IL13 from Th2 cells and granulocytes. IL4 is an early innate signal released during tissue injury, stimulating macrophage arginase to convert arginine to ornithine which is a step in extra-cellular matrix collagen production [93]. This ornithine is a precursor for polyamines which have an effect on cytokine production, affording wound healing macrophages regulatory capabilities [94].

Regulatory macrophages, with anti-inflammatory activity, are most reliably defined and identified through IL10 levels or IL10/IL12 ratio (as they also downregulate IL12 [95]). These develop in response to a large number of stimuli, including IL10 produced by regulatory $\mathrm{T}$ cells, TGF $\beta$ [96], and glucocorticoids. The latter attenuate macrophage-mediated inflammation through inhibition of pro-inflammatory cytokine gene transcription [97], nonetheless capacity for phagocytosis does not appear to be impaired by glucocorticoids [98]. Unlike wound-healing macrophages, regulatory macrophages do not contribute to the production of extracellular matrix.

\section{Macrophage activation pathways in atherosclerosis}

Following the priming stage, activation of macrophages is reliant upon ligation of pattern recognition receptors (PRR) [29,99], namely nucleotide-binding oligomerisation domain (NOD)-like receptors (NLRs) and TLRs.

\section{Toll-like receptor signalling}

TLRs are the most well-characterised PRRs, of which at least ten have been identified in humans [100]. TLRs may be found on the cell surface, as in the case of TLRs $1,2,4,5$ and 6 , or reside intracellularly [101,102]. TLRs are key activators of monocytes and macrophages.

Upon exposure to ligand, TLRs couple to signalling adaptors to induces two major downstream signalling pathways: the nuclear factor kappa B (NF $\kappa \mathrm{B})$ (Figure 2) and the interferon response factor (IRF) pathways. MyD88 is a universal adapter protein that carries signalling through all TLRs, except TLR3, leading to the activation of $\mathrm{NF} \kappa \mathrm{B}$. MyD88-dependent signalling relies on recruitment of Mal (MyD88-adaptor like), which leads to the recruitment of the IL1 receptor-associated kinase (IRAK). Phosphorylation of IRAK signals to tumournecrosis-factor-receptor-associated factor 6 (TRAF6). 


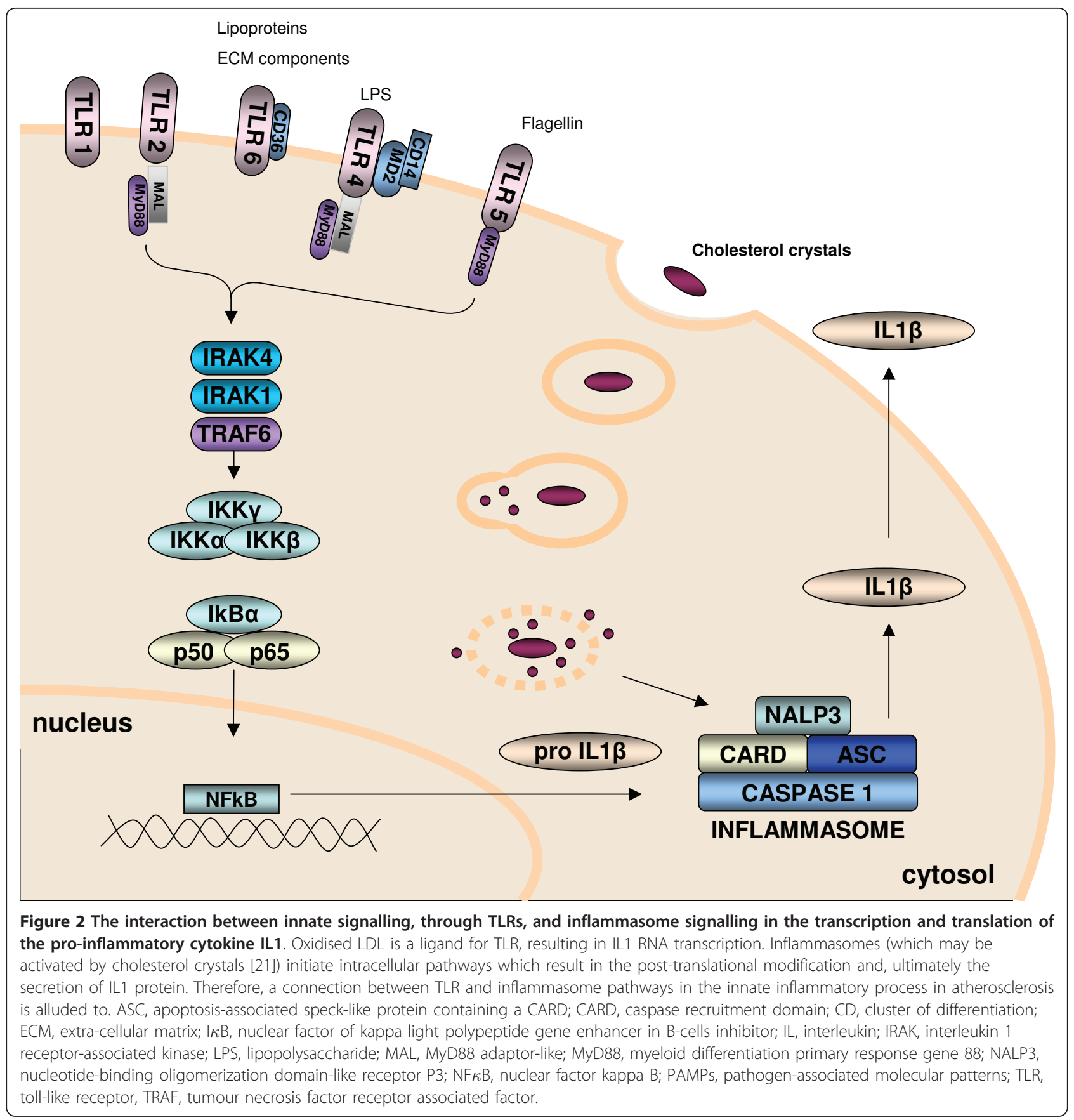

The subsequent nuclear translocation of $\mathrm{NF} \kappa \mathrm{B}$ and translation of inflammatory cytokines is driven by phosphorylation of the I $\kappa \mathrm{B}$ kinase (IKK) complex upon activation of TRAF6. MyD88-independent signalling is via TRAM (TRIF-related adaptor molecule) and TRIF (TIRdomain-containing adaptor protein inducing IFN $\beta$ ), and can activate both $\mathrm{NF} \kappa \mathrm{B}$ and IRF, inducing interferon synthesis. The importance of IL1/TLR signalling in atherosclerosis has been further highlighted by work implicating IRAK4 kinase in modified LDL-medicated experimental atherosclerosis [103].

The most characterised recognition system is the one sensing LPS. Serum LPS-binding protein (LBP) transfers LPS to CD14, which delivers it to the co-receptor MD2 $[104,105]$. The availability of all members of the complex dictates the sensitivity of recognition of endotoxin at extremely low concentrations. Cells that do not express CD14, such as endothelial cells, are relatively unresponsive compared to $\mathrm{CD} 14^{+}$monocytes $[104,105]$. 
CD14 acts as a co-receptor (along with TLR4 and MD2) for the detection of bacterial LPS. CD14, however, can only bind LPS in the presence of LBP. TLR2 may also be activated via scavenger co-receptors, including CD36 [106].

\section{Toll-like receptor agonists}

Initially, ligands binding to PRRs such as TLRs on/in innate immune cells were believed to be of a pathogenic aetiology; molecules or small molecular motifs derived from, conserved within or associated with groups of microorganisms (such as bacterial LPS). These have been nominated pathogen associated molecular patterns (PAMPs). More recently, such ligands have been classified as danger associated molecular patterns (DAMPs) encompassing a wider definition which embodies the existence of endogenous danger signals. The concept that oxidation reactions involving lipids, proteins and DNA produce non-microbial 'oxidation-specific epitopes' has emerged [107]. Of particular interest is that host-derived oxidation-specific epitopes represent endogenous DAMPs, are recognised by PRRs and are capable of driving the inflammation seen in atherosclerosis [107].

DAMPs that may bind TLRs are numerous, some of which have been proposed as endogenous culprits in atherosclerosis. Examples of endogenous ligands to TLR2 include necrotic cell products [108], apolipoprotein CIII [109], serum amyloid A [110], versican [111]. Furthermore, oxidised phospholipids, saturated fatty acids, and lipoprotein A have been shown to trigger macrophage apoptosis, under conditions of thapsigargininduced endoplasmic reticulum stress, via a mechanism requiring both CD36 and TLR2 [112].

Hyaluronan fragment [113], biglycan [114], oxLDL $[115,116]$ and heat shock proteins [117] have been shown to act through both TLR2 and TLR4. Long surfactant protein A [118], tenascin C [119], fibrinogen [120], fibronectin EDA [121], heparan sulphate [122], $\beta$ defensin 2 [123], amyloid $\beta$ peptide [24] and minimally modified LDL (mmLDL) [23] act via TLR4 alone. TLR3 detects mRNA [124,125], whilst TLR7 and TLR9 detect nucleic acid-containing immune complexes [126,127]. TLRs 5,6 and 8 are yet to have endogenous ligands allocated to them [25].

Although both mmLDL and oxLDL are seen as ligands to TLR4, the pathways by which recognition occurs differ. The recognition of mmLDL is similar to that of LPS and involves CD14 and MD2 [22], whilst oxLDL initiates inflammatory responses through a TLR4/TLR6 heterodimer in association with CD36 but independently of CD14 [128]. A lipidic component of LDL, namely oxPAPC, has been shown as capable of inducing IL8 transcription via TLR4 in a manner which is independent of both CD14 and CD36 [129]. Further work, however, has seen oxPAPC inhibiting TLR4dependent IL8 induction, along with inhibition of Eselectin and CCL2, whilst IL1 $\beta$ and TNF $\alpha$ signalling remained unhindered [130]. Downstream of TLR4/ MD2/CD14, intracellular signalling in response to mmLDL stimulation has been investigated and, in addition to the canonical MyD88 pathway, an alternative pathway via sequential activation of spleen tyrosine kinase (Syk), phospholipase $C \gamma 1$, protein kinase $C$, and NADPH oxidase 2 (gp91phox/Nox2) has been proposed in the stimulation of pro-inflammatory cytokine production and the effects thereof [131].

\section{Toll-like receptor expression in atherosclerosis}

TLRs are differentially expressed by the various cell types in atherosclerosis, with TLR2 and TLR4 found on monocytes, macrophages, foam cells and myeloid DCs, as well as smooth muscle cells and B lymphocytes (reviewed by [25]). Human and mouse atherosclerosis is characterised by an increased expression of TLR1, TLR2 and TLR4 (and to some extent TLR5), mainly by macrophages and endothelial cells [116,132]. In mouse atherosclerosis, TLR4 expression is exclusively by macrophages [116]. There has been shown to be co-localisation of p65 (an NF $\kappa$ B family member) with both TLR2 and TLR4 in macrophages in atherosclerosis [132].

The differential expression of the various TLRs by monocyte subsets and macrophage subtypes remains largely unknown at present, however there is some data to support the relative transcription of TLR5 being higher in M2 polarised human macrophages as compared with M1 [28]. The circulating monocytes of ApoE $^{-/-}$mice with advanced atherosclerosis have increased TLR2 and TLR4 expression [133]. This is also the case for monocytes from patients with arterial disease when comparison is made with controls subjects [134-137]. Interestingly, enhanced TLR signalling is restricted to patients with acute coronary syndromes [138-140].

\section{Role of Toll-like receptors in atherosclerosis}

When recognising ligands, the majority of TLRs associate the signalling adaptor MyD88 to initiate an intracellular signalling cascade. More specifically, removing the MyD88 pathway led to a reduction in aortic atherosclerosis (by approximately 60\%) and a decrease in macrophage recruitment to the artery wall (by approximately 75\%), associated with reduced chemokine levels $[141,142]$. In a functional human atherosclerosis study, a significant reduction of pro-inflammatory cytokines and MMPs was found after MyD88 inhibition [143].

The role of TLR2 and TLR4 has been extensively studied in models of atherosclerosis. The first indication of a role for TLR4 in atherosclerosis came from the finding that $\mathrm{C} 3 \mathrm{H} / \mathrm{HeJ}$ mice - that hold a missense mutation of TLR4's cytoplasmic component - are resistant to 
atherosclerosis $[144,145]$. In accordance, specific deletion of TLR4 in $\mathrm{ApoE}^{-/-}$mice resulted in a $24 \%$ reduction in whole aortic atherosclerotic lesion area and significantly attenuated macrophage infiltration within these lesions [141]. TLR2 deletion in $\mathrm{LDLR}^{-/}$mice limits lesion area by between a third and two-thirds [141,146-148], reducing intra-lesion inflammation as evidenced by a reduction in total infiltrating macrophage numbers [147,148], and attenuates macrophage to smooth muscle cell ratio and extent of apoptosis [147].

Both TLR2 and TLR4 are known to be important in post-vascular injury neo-intimal lesion formation $[149,150]$. In a hypercholesterolaemic rabbit model of atherosclerosis, carotid artery liposomal transfection of TLR2 and TLR4 cDNA revealed that upregulation of either TLR alone did not significantly affect carotid atherosclerosis. Interestingly, transfection of both TLR2 and TLR4 together resulted in a synergistic acceleration of atherosclerosis [151]. Recently, $\mathrm{LDLR}^{-/-}$mice transplanted with TLR2 $2^{-1-} \mathrm{TLR}^{-1-}$ bone marrow displayed a reduction in both macrophage apoptosis and atherosclerotic plaque necrosis as compared with $\mathrm{LDLR}^{-/-}$ mice transplanted with wild-type bone marrow, supporting an additive effect of TLR2 and TLR4 in murine atherosclerosis [112].

A different picture came from bone marrow chimera studies. Bone marrow transplantation from $\mathrm{TLR}^{-/-}$to $\mathrm{LDLR}^{-/-}$mice was unable to prevent diet-induced atherosclerotic lesions [146]. Bone marrow transfer from $\mathrm{C} 3 \mathrm{H} / \mathrm{HeJ}$ to ApoE knockouts did not alter atherosclerosis susceptibility [152]. Synthetic TLR2 ligand administered dramatically increases atherosclerosis in $\mathrm{LDLR}^{-/-}$ mice, with TLR2 deficient bone marrow transfer into this model preventing TLR2 ligand-induced atheroma [146]. Such studies raise the question of whether TLR2 signalling in myeloid cells is relevant in atherosclerosis, as compared with TLR2 expression by cells resident in the arterial wall. Importantly, it supports the role of endogenous TLR2 ligand action on myeloid cells in atherosclerosis, with exogenous agonists activating TLR2 on cells of a non-myeloid lineage.

What are the mechanisms through which TLR exert proatherogenic actions? Importantly, TLR2, TLR4 and TLR9 ligands promote lipid uptake by macrophages and, hence, foam cell formation [111,153-155]. Differentiated macrophages exhibit macropinocytosis (fluid phase uptake of lipids) which is dependent upon TLR4 [156]. However, the effect of TLR signalling are not limited to foam cell formation but have a direct effect on inflammation and matrix degradation.

Functional studies on human carotid endarterectomy specimens have shown sustained TLR2 activation in cells isolated from human atheromata [143]. TLR2 and MyD88 play a key role in $\mathrm{NF} \kappa \mathrm{B}$ activation, and in the production of inflammatory mediators CCL2, IL6, IL8, MMPs 1, 2, 3 and 9 [143]. Conversely TLR4, and its downstream signalling adaptor TRAM, were shown not to be rate-limiting for cytokine production in this context. This adds weight to the role of some (but not all) TLRs in plaque vulnerability.

Furthermore, and as alluded to above, TLR ligation may influence atherosclerosis through alterations in MMP and TIMP expression. The effect of LPS on human blood monocytes has been investigated and MMP3 is upregulated [157], whilst MMPs 1, 2, 7, 10 and 14 and TIMPs 1, 2 and 3 are not upregulated by LPS $[157,158]$. Controversially, two separate studies have found upregulation [159] and no upregulation [157] of MMP9 in human blood monocytes stimulated with LPS. In human macrophages (from various sites) meanwhile, MMPs 2, 3, 8, 9 and 14, and TIMP1 have all been upregulated by LPS [158,160-163].

Using both human and murine models of atherosclerosis, we have investigated the consequence of endosomal TLRs in atherosclerosis and arterial injury. Deficiency of TLR3 accelerates the onset of atherosclerosis in $\mathrm{ApoE}^{-/-}$mice. Moreover, genetic deletion of TLR3 dramatically enhanced the development of elastic lamina breakages after collar-induced injury. The systemic (intraperitoneal) administration of doublestranded RNA (dsRNA) - a TLR3 agonist - decreased neointima formation upon arterial injury. Genetic deletion of TLR3 was associated with the presence of large interruptions of the elastic lamina after the placement of a perivascular collar for arterial injury development. Finally, lesion development in both human and mice was associated in an increase of expression of TLR3 and TLR3-associated responses, in particular in smooth muscle cells pointing to this cell type as the carrier of the protective effect. This data shows for the first time that while extracellular TLRs may be detrimental to atherosclerosis, intracellular TLRs may offer protection against hypercholesterolemia and injury-induced lesions. The mechanism of TLR3-induced protection is currently unknown. IFN $\beta$ production - that is a consequence of TLR3 dependent signalling - has been associated with a reduction in inflammasome activation and IL1 signalling, as well as with induction of IL10 [164]. However, it is uncertain whether the vasculoprotective effect of TLR3 may be mediated via IFN $\beta$. Although IFN $\beta$ has been shown to be effective in an arterial injury model [165], a more recent report showed a potential deleterious role in atherosclerosis induced by hyperlipidemia [166]. It is also uncertain whether synthetic dsRNA is safe as therapeutic tool, as its administration elicits both pro-inflammatory and anti-inflammatory mediators [124]. Moreover, a recent study showed that dsRNA intravenous administration at high doses may lead to 
endothelial cell apoptosis and increased vascular lesion formation [167]. Further studies are needed to elucidate the mechanisms of vasculoprotection elicited by TLR3. TLR3 activation has been shown to elicit the production in the vasculature of IL10 [124] and of the B7 family members programmed cell death ligands PDL1 and PDL2, which are known to contribute to vascular protection $[168,169]$.

It is also unknown what endogenous agonists of TLR3 may be involved in protection, as the genetic removal of TLR3 accelerates atherosclerosis and elastic lamina damage. Interestingly, stathmin, a protein that participates in microtubule assembly and is upregulated in brain injury, has been described as a candidate TLR3 agonist and has been linked to the induction of a neuroprotective gene profile [170].

\section{NOD-like receptors and inflammasomes and atherogenesis}

NLRs are PRRs that sense intra-cellular microbial and non-microbial signals, in a similar fashion to the extracellular detection of these entities by most TLRs. NLRs have the capacity to form large cytoplasmic complexes known as "inflammasomes" (reviewed in [171]) through the assembly of NLRs, caspase and apoptosis-associated speck-like protein containing a caspase recruitment domain (ASC). ASC acts to link the NLR and caspase, the latter of which are usually caspase 1 and 11 [172]. The inflammasome acts as a scaffold for the activation of caspase 1 as its central effector molecule [173]. Upon activation, inflammasome caspase 1 proteolytically activates pro-inflammatory cytokines, notably the conversion of pro-IL1 $\beta$ and pro-IL18 to IL1 $\beta$ and IL18, respectively.

It is largely agreed that inflammasome activation resulting in active IL1 $\beta$ release requires two separate signals [174]. A priming signal may be triggered by TLR activation, with resultant $\mathrm{NF} \kappa \mathrm{B}$ production leading to pro-IL1 $\beta$ synthesis, as well as inflammasome components such as caspase 11 [173]. Recognition of peptidoglycan by NOD1 and NOD2 can also trigger activation of $\mathrm{NF} \kappa \mathrm{B}$ signal transduction through Rip2 kinase [100]. The second signal, which activates the caspase 1 of a complete inflammasome, allowing the conversion of available pro-IL1 $\beta$ to IL1 $\beta$ includes activation by ATP of the $\mathrm{P}_{2} \mathrm{X}_{7}$ purinergic receptor with potassium efflux. The second signal may also be achieved by PAMPs such as bacterial toxins and viral DNA, or other DAMPs including oxidative stress, large particles and ultraviolet light [171].

Inflammasomes have been described in a number of inflammatory conditions [171] and evidence for their role in atherosclerosis is emerging. The NLRP3 inflammasome is currently the most characterised inflammasome (Figure 2). Recent work has shown that cholesterol crystals activate the NLRP3 inflammasome, which in turn results in cleavage and secretion of IL1 family cytokines [21]. Furthermore, LDLR-deficient mice transplanted with NLRP3-deficient bone marrow and fed a high-cholesterol diet had markedly decreased early atherosclerosis and inflammasome-dependent IL18 levels [21]. $\mathrm{LDLR}^{-1-}$ mice bone-marrow transplanted with ASC-deficient or IL- $1 \alpha / \beta$-deficient bone marrow and fed on a high-cholesterol diet had consistent and marked reductions in both atherosclerosis and IL18 production [21]. Furthermore, ASC deficiency also attenuates neointimal formation after vascular injury via reduced expression of IL1 $\beta$ and IL18, with $\mathrm{ASC}^{-/-}$bone marrow chimeras also exhibiting significantly reduced neointimal formation [175]. These findings taken together suggest that crystalline cholesterol acts as an endogenous danger signal, its deposition in arteries being an early cause rather than a late consequence of inflammation.

Both IL1 and IL18 signal through MyD88, and their absence in experimental mouse atherosclerosis also has the effect of limiting atherosclerosis development $[176,177]$. Devlin et al showed that IL1ra knockout mice on a cholesterol/chocolate diet, exhibited a 3-fold decrease in non-high-density lipoprotein (HDL) cholesterol and a trend toward increased foam cell lesion area compared to controls [178]. Complementing this experiment they showed, conversely, that increased IL1ra expression (using an IL1ra transgenic/LDLR ${ }^{-/-}$mouse on a cholesterol-saturated fat diet) resulted in a $40 \%$ increase in non-HDL cholesterol levels. Thus concluding that under certain conditions, chronic IL1ra depletion or over-expression could have an important effect on lipid metabolism.

This was also verified in human atherosclerotic arteries [179], although more recently, IL1ra administration has been shown to have lesser effect on inflammatory molecule production when compared to TLR inhibition in the context of human atherosclerosis [143].

\section{Macrophage deactivation pathways in atherosclerosis}

PPAR $\gamma$ has recently been highlighted as an important determinant of macrophage phenotype and function (Figure 3), which may explain the favourable effect of PPAR $\gamma$ modulation in experimental atherosclerosis $[180,181]$. PPAR $\gamma$ is a ligand-activated nuclear receptor involved in reverse cholesterol transport and other metabolic cellular activities [46]. Its anti-inflammatory properties occur through negative interference with nuclear factor $\kappa \mathrm{B}(\mathrm{NF} \kappa \mathrm{B})$, signal transducer and activator of transcription (STAT), and activating protein 1 (AP1) pathways [182]. PPAR $\gamma$ is strongly induced by IL4 $[40,183]$. PPAR $\gamma$ upregulation may also be stimulated by oxidised LDL, with PPAR $\gamma$ being highly expressed in the foam cells of atherosclerotic lesions, and ligand 


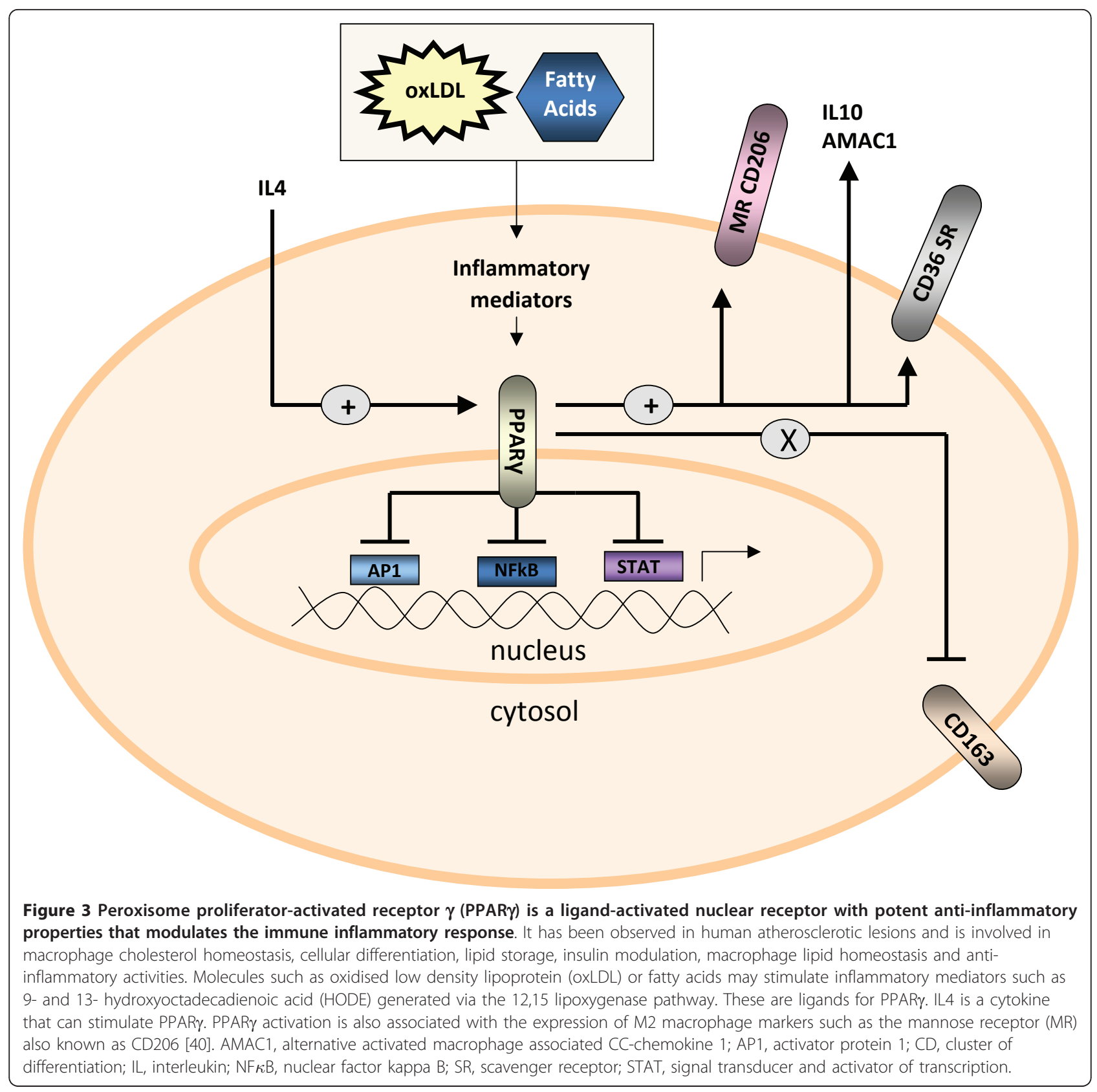

activation of PPAR $\gamma$ promoting oxidised LDL uptake and foam cell formation [184].

The functional relationship between PPAR $\gamma$ and the wound healing M2-type macrophage phenotype $[185,186]$ has been proposed through the positive correlation between PPAR $\gamma$ expression levels and the M2 markers CD206 [187], CD36 scavenger receptor [184], IL10 [188] and alternative activated macrophage associated CC-chemokine 1 (AMAC1; CCL18) [40]. Primary human monocytes differentiated in vitro with IL4 in the presence of PPAR $\gamma$ agonist (termed M2 $\gamma$ macrophages) resulted in increased CD206 and reduced CD163 expression, above and beyond that which was seen with IL4 alone [40] (Figure 3). M2 $\gamma$ culture supernatant exerted a greater anti-inflammatory effect on M1 macrophages as compared with M2 culture supernatant [40]. Subsequent work has shown that M2 $\gamma$ macrophages have down-regulation of the nuclear liver $\times$ receptor $\alpha$ with resultant enhanced phagocytosis but reduced cholesterol handling [41]. PPAR $\gamma$ also limits MMP9 through inhibition of $\mathrm{NF} \kappa \mathrm{B}$ activation [189].

However, in the clinical arena, PPAR $\gamma$ agnonists have been shown to have complex and opposing effects on circulating levels of pro- and anti-inflammatory 
molecules [190-193]. Furthermore, macrophages have been observed adhering to areas of intimal thickening in PPAR $\gamma$-dependent manner [194].

\section{Conclusions}

Macrophages have been shown to exert a number of diverse functions in atherosclerosis, including inflammation, lipid metabolism and matrix degradation Recent studies have highlighted significant heterogeneity in macrophage behaviour and activation within atherosclerotic plaque. This heterogeneity is derived both from the heterogeneity of originating monocytes, and the inflammatory and lipidic stimuli available in the plaque. It is known that signalling pathways related to innate immunity are strong determinants for macrophage activation and there is growing evidence that they have a significant effect in plaque development and the complications thereof. Innate immune pathways may be activated by both infectious pathogens and endogenous danger signals. An example of the latter is the recognition by innate immune receptors of a growing number of lipoprotein components that are vital to the development of atherosclerosis. Oxidised LDL is seen to signal through TLR [22-24], cholesterol crystals signalling through NLR [21], and oxPAPC signalling via NRF2 [36]. The convergence of these pathways gives rise to the activation of resident monocyte-macrophages leading to cytokine and chemokine production. Moreover, TLR activation might have a role in biasing macrophage polarisation towards an M1 phenotype, together with Th1 lymphocytes present in the plaque. These exciting new findings highlight a wealth of novel potential therapeutic and diagnostic targets that may be exploited in the future treatment of cardiovascular disease.

\section{Acknowledgements}

Mr Joseph Shalhoub's research is supported by the Circulation Foundation Mary Davies Research Fellowship, the Royal College of Surgeons of England/ Rosetrees Trust Research Fellowship, the Graham-Dixon Charitable Trust and the Peel Medical Research Trust.

Dr Claudia Monaco has received funding from: the British Heart Foundation; European Commission under the 6th Framework Programme through the SME call for "Life sciences, genomics and biotechnology for health" (Contract number: LSHM-CT-2006-037400); European Collaborative Project on Inflammation and Vascular Wall Remodelling in Atherosclerosis Acronym: AtheroRemo; EU - HEALTH-2007-2.4.2-1. 2008; the Graham-Dixon Charitable Trust; the Kennedy Trustees. The Kennedy Institute of Rheumatology is funded by the Arthritis Research Campaign UK.

\section{Author details}

${ }^{1}$ Cytokine Biology of Atherosclerosis, Kennedy Institute of Rheumatology, Faculty of Medicine, Imperial College London, UK. ${ }^{2}$ Academic Section of Vascular Surgery, Department of Surgery and Cancer, Faculty of Medicine, Imperial College London, UK.

\section{Authors' contributions}

All authors were involved directly in the drafting and critical revision of this review. CM is the senior author with overall responsibility for this work, giving the final approval for publication. All authors have read and approved the final manuscript.

\section{Competing interests}

The authors declare that they have no competing interests.

Received: 16 September 2010 Accepted: 28 April 2011

Published: 28 April 2011

\section{References}

1. Lopez AD, Mathers CD, Ezzati M, Jamison DT, Murray CJ: Global and regional burden of disease and risk factors, 2001: systematic analysis of population health data. Lancet 2006, 367(9524):1747-57.

2. Global Burden of Disease Study Operations Manual. Harvard University, University of Washington, Johns Hopkins University, University of Queensland, World Health Organization; 2009.

3. Mayerl C, Lukasser M, Sedivy R, Niederegger H: Atherosclerosis research from past to present-on the track of two pathologists with opposing views, Carl von Rokitansky and Rudolf Virchow. Virchows Archiv 2006.

4. Methe $H$, Weis M: Atherogenesis and inflammation-was Virchow right? Nephrology Dialysis Transplantation 2007.

5. Ross R: Atherosclerosis-an inflammatory disease. N Engl J Med 1999, 340(2):115-26.

6. Ridker PM, Danielson E, Fonseca FA, Genest J, Gotto AM Jr, Kastelein JJ, Koenig W, Libby P, Lorenzatti AJ, MacFadyen JG, Nordestgaard BG, Shepherd J, Willerson JT, Glynn RJ: Rosuvastatin to prevent vascular events in men and women with elevated C-reactive protein. $N$ Engl J Med 2008, 359(21):2195-207.

7. Full $L$, Ruisanchez $C$, Monaco $C$ : The inextricable link between atherosclerosis and prototypical inflammatory diseases rheumatoid arthritis and systemic lupus erythematosus. Arthritis Res Ther 2009, 11(2):217.

8. Haque $\mathrm{S}$, Mirjafari $\mathrm{H}$, Bruce IN: Atherosclerosis in rheumatoid arthritis and systemic lupus erythematosus. Curr Opin Lipidol 2008, 19(4):338-43.

9. Glass CK, Witztum JL: Atherosclerosis. the road ahead. Cell 2001, 104(4):503-16.

10. Caro CG: Discovery of the role of wall shear in atherosclerosis. Arterioscler Thromb Vasc Biol 2009, 29(2):158-61

11. Cheng C, Tempel D, van Haperen R, van der Baan A, Grosveld F, Daemen MJ, Krams R, de Crom R: Atherosclerotic lesion size and vulnerability are determined by patterns of fluid shear stress. Circulation 2006, 113(23):2744-53.

12. Davies MJ, Richardson PD, Woolf $N$, Katz DR, Mann J: Risk of thrombosis in human atherosclerotic plaques: role of extracellular lipid, macrophage, and smooth muscle cell content. Br Heart J 1993, 69(5):377-81.

13. van der Wal $A C$, Becker $A E$, van der Loos CM, Das PK: Site of intimal rupture or erosion of thrombosed coronary atherosclerotic plaques is characterized by an inflammatory process irrespective of the dominant plaque morphology. Circulation 1994, 89(1):36-44.

14. Virmani R, Burke AP, Kolodgie FD, Farb A: Pathology of the thin-cap fibroatheroma: a type of vulnerable plaque. J Interv Cardiol 2003, 16(3):267-72.

15. Gleissner CA, Shaked I, Little KM, Ley K: CXC chemokine ligand 4 induces a unique transcriptome in monocyte-derived macrophages. $J$ Immunol 2010, 184(9):4810-8.

16. Tedgui A, Mallat Z: Cytokines in atherosclerosis: pathogenic and regulatory pathways. Physiol Rev 2006, 86(2):515-81.

17. Mauriello A, Sangiorgi GM, Virmani R, Trimarchi S, Holmes DR Jr Kolodgie FD, Piepgras DG, Piperno G, Liotti D, Narula J, Righini P, Ippoliti A, Spagnoli LG: A pathobiologic link between risk factors profile and morphological markers of carotid instability. Atherosclerosis 2010, 208(2):572-80

18. Grabner R, Lotzer K, Dopping S, Hildner M, Radke D, Beer M, Spanbroek R, Lippert B, Reardon CA, Getz GS, Fu YX, Hehlgans T, Mebius RE, van der Wall M, Kruspe D, Englert C, Lovas A, Hu D, Randolph GJ, Weih F, Habenicht AJ: Lymphotoxin beta receptor signaling promotes tertiary lymphoid organogenesis in the aorta adventitia of aged ApoE-/- mice. J Exp Med 2009, 206(1):233-48.

19. Dunmore BJ, McCarthy MJ, Naylor AR, Brindle NP: Carotid plaque instability and ischemic symptoms are linked to immaturity of microvessels within plaques. J Vasc Surg 2007, 45(1):155-9. 
20. Narula J, Strauss HW: The popcorn plaques. Nat Med 2007, 13(5):532-4.

21. Duewell P, Kono H, Rayner KJ, Sirois CM, Vladimer G, Bauernfeind FG, Abela GS, Franchi L, Nunez G, Schnurr M, Espevik T, Lien E, Fitzgerald KA, Rock KL, Moore KJ, Wright SD, Hornung V, Latz E: NLRP3 inflammasomes are required for atherogenesis and activated by cholesterol crystals. Nature 2010, 464(7293):1357-61.

22. Miller YI, Viriyakosol S, Binder CJ, Feramisco JR, Kirkland TN, Witztum JL: Minimally modified LDL binds to CD14, induces macrophage spreading via TLR4/MD-2, and inhibits phagocytosis of apoptotic cells. J Biol Chem 2003, 278(3):1561-8.

23. Miller YI, Viriyakosol S, Worrall DS, Boullier A, Butler S, Witztum JL: Toll-like receptor 4-dependent and -independent cytokine secretion induced by minimally oxidized low-density lipoprotein in macrophages.

Arteriosclerosis, Thrombosis, and Vascular Biology 2005, 25(6):1213-9.

24. Stewart CR, Stuart LM, Wilkinson K, van Gils JM, Deng J, Halle A, Rayner KJ, Boyer L, Zhong R, Frazier WA, Lacy-Hulbert A, Khoury JE, Golenbock DT, Moore KJ: CD36 ligands promote sterile inflammation through assembly of a Toll-like receptor 4 and 6 heterodimer. Nat Immunol 2010, 11(2):155-61

25. Cole JE, Georgiou E, Monaco C: The Expression and Functions of Toll-Like Receptors in Atherosclerosis. Mediators of Inflammation 2010.

26. Van Ginderachter JA, Movahedi K, Hassanzadeh Ghassabeh G, Meerschaut S, Beschin A, Raes G, De Baetselier P: Classical and alternative activation of mononuclear phagocytes: picking the best of both worlds for tumor promotion. Immunobiology 2006, 211(6-8):487-501.

27. Waldo SW, Li Y, Buono C, Zhao B, Billings EM, Chang J, Kruth HS: Heterogeneity of human macrophages in culture and in atherosclerotic plaques. Am J Pathol 2008, 172(4):1112-26.

28. Martinez FO, Gordon S, Locati M, Mantovani A: Transcriptional profiling of the human monocyte-to-macrophage differentiation and polarization: new molecules and patterns of gene expression. J Immunol 2006, 177(10):7303-11.

29. Gordon S: Alternative activation of macrophages. Nat Rev Immunol 2003, 3(1):23-35.

30. Gordon S: The macrophage: past, present and future. Eur J Immunol 2007, 37(Suppl 1):S9-17.

31. Mosser DM, Edwards JP: Exploring the full spectrum of macrophage activation. Nat Rev Immunol 2008, 8(12):958-69.

32. Mantovani A, Garlanda C, Locati M: Macrophage diversity and polarization in atherosclerosis: a question of balance. Arterioscler Thromb Vasc Biol 2009, 29(10):1419-23

33. Hansson GK: Atherosclerosis An immune disease: The Anitschkov Lecture 2007. Atherosclerosis 2008, 1-9.

34. Mallat $Z$, Taleb S, Ait-Oufella H, Tedgui A: The role of adaptive T cell immunity in atherosclerosis. J Lipid Res 2009, 50(Suppl):S364-9.

35. Khallou-Laschet J, Varthaman A, Fornasa G, Compain C, Gaston AT, Clement M, Dussiot M, Levillain O, Graff-Dubois S, Nicoletti A, Caligiuri G: Macrophage plasticity in experimental atherosclerosis. PLoS One 2010, 5(1):e8852.

36. Kadl A, Meher AK, Sharma PR, Lee MY, Doran AC, Johnstone SR, Elliott MR, Gruber F, Han J, Chen W, Kensler T, Ravichandran KS, Isakson BE, Wamhoff BR, Leitinger N: Identification of a novel macrophage phenotype that develops in response to atherogenic phospholipids via Nrf2. Circ Res 2010, 107(6):737-46.

37. Mantovani A, Sica A, Sozzani S, Allavena P, Vecchi A, Locati M: The chemokine system in diverse forms of macrophage activation and polarization. Trends Immunol 2004, 25(12):677-86.

38. Miller AM, Xu D, Asquith DL, Denby L, Li Y, Sattar N, Baker AH, Mclnnes IB, Liew FY: IL-33 reduces the development of atherosclerosis. J Exp Med 2008, 205(2):339-46.

39. Miller AM, Asquith DL, Hueber AJ, Anderson LA, Holmes WM, McKenzie AN, Xu D, Sattar N, McInnes IB, Liew FY: Interleukin-33 induces protective effects in adipose tissue inflammation during obesity in mice. Circ Res 2010, 107(5):650-8.

40. Bouhlel MA, Derudas B, Rigamonti E, Dievart R, Brozek J, Haulon S, Zawadzki C, Jude B, Torpier G, Marx N, Staels B, Chinetti-Gbaguidi G: PPARgamma activation primes human monocytes into alternative M2 macrophages with anti-inflammatory properties. Cell Metab 2007, 6(2):137-43.

41. Chinetti-Gbaguidi G, Baron M, Bouhlel MA, Vanhoutte J, Copin C, Sebti Y, Derudas B, Mayi T, Bories G, Tailleux A, Haulon S, Zawadzki C, Jude B,
Staels B: Human Atherosclerotic Plaque Alternative Macrophages Display Low Cholesterol Handling but High Phagocytosis Because of Distinct Activities of the PPAR\{gamma\} and LXR\&alpha; Pathways. Circ Res 2011.

42. Boyle JJ, Harrington HA, Piper E, Elderfield K, Stark J, Landis RC, Haskard DO: Coronary intraplaque hemorrhage evokes a novel atheroprotective macrophage phenotype. Am J Pathol 2009, 174(3):1097-108.

43. Chase AJ, Bond M, Crook MF, Newby AC: Role of nuclear factor-kappa B activation in metalloproteinase- $1,-3$, and -9 secretion by human macrophages in vitro and rabbit foam cells produced in vivo. Arterioscler Thromb Vasc Biol 2002, 22(5):765-71.

44. Johnson JL, Sala-Newby GB, Ismail Y, Aguilera CM, Newby AC: Low tissue inhibitor of metalloproteinases 3 and high matrix metalloproteinase 14 levels defines a subpopulation of highly invasive foam-cell macrophages. Arterioscler Thromb Vasc Biol 2008, 28(9):1647-53.

45. Thomas AC, Sala-Newby GB, Ismail Y, Johnson JL, Pasterkamp G, Newby AC: Genomics of foam cells and nonfoamy macrophages from rabbits identifies arginase-I as a differential regulator of nitric oxide production. Arterioscler Thromb Vasc Biol 2007, 27(3):571-7.

46. Gordon S, Martinez FO: Alternative activation of macrophages: mechanism and functions. Immunity 2010, 32(5):593-604.

47. Geissmann F, Jung S, Littman DR: Blood monocytes consist of two principal subsets with distinct migratory properties. Immunity 2003, 19(1):71-82.

48. Fleming TJ, O'HUigin C, Malek TR: Characterization of two novel Ly-6 genes. Protein sequence and potential structural similarity to alphabungarotoxin and other neurotoxins. J Immunol 1993, 150(12):5379-90.

49. Strauss-Ayali D, Conrad SM, Mosser DM: Monocyte subpopulations and their differentiation patterns during infection. J Leukoc Biol 2007, 82(2):244-52.

50. Gautier EL, Jakubzick C, Randolph GJ: Regulation of the migration and survival of monocyte subsets by chemokine receptors and its relevance to atherosclerosis. Arterioscler Thromb Vasc Biol 2009, 29(10):1412-8.

51. Steinman RM, Idoyaga J: Features of the dendritic cell lineage. Immunol Rev 2010, 234(1):5-17.

52. Passlick B, Flieger D, Ziegler-Heitbrock HW: Identification and characterization of a novel monocyte subpopulation in human peripheral blood. Blood 1989, 74(7):2527-34.

53. Ziegler-Heitbrock HW, Fingerle G, Strobel M, Schraut W, Stelter F, Schutt C, Passlick B, Pforte A: The novel subset of CD14+/CD16+ blood monocytes exhibits features of tissue macrophages. Eur J Immunol 1993, 23(9):2053-8.

54. Ancuta P, Rao R, Moses A, Mehle A, Shaw S, Luscinskas F, Gabuzda D: Fractalkine preferentially mediates arrest and migration of CD16+ monocytes. J Exp Med 2003, 197(12):1701-7.

55. Weber C, Belge KU, von Hundelshausen P, Draude G, Steppich B, Mack M, Frankenberger M, Weber KS, Ziegler-Heitbrock HW: Differential chemokine receptor expression and function in human monocyte subpopulations. $J$ Leukoc Biol 2000, 67(5):699-704

56. Tacke F, Alvarez D, Kaplan TJ, Jakubzick C, Spanbroek R, Llodra J, Garin A, Liu J, Mack M, van Rooijen N, Lira SA, Habenicht AJ, Randolph GJ: Monocyte subsets differentially employ CCR2, CCR5, and CX3CR1 to accumulate within atherosclerotic plaques. J Clin Invest 2007, 117(1):185-94.

57. Palframan RT, Jung $S$, Cheng G, Weninger W, Luo Y, Dorf M, Littman DR, Rollins BJ, Zweerink H, Rot A, von Andrian UH: Inflammatory chemokine transport and presentation in HEV: a remote control mechanism for monocyte recruitment to lymph nodes in inflamed tissues. J Exp Med 2001, 194(9):1361-73

58. Gordon S, Taylor PR: Monocyte and macrophage heterogeneity. Nat Rev Immunol 2005, 5(12):953-64.

59. Ingersoll MA, Spanbroek R, Lottaz C, Gautier EL, Frankenberger M, Hoffmann R, Lang R, Haniffa M, Collin M, Tacke F, Habenicht AJ, ZieglerHeitbrock L, Randolph GJ: Comparison of gene expression profiles between human and mouse monocyte subsets. Blood 2010, 115(3): e10-9.

60. Swirski F, Libby P, Aikawa E, Alcaide P, Luscinskas F, Weissleder R, Pittet M: Ly-6Chi monocytes dominate hypercholesterolemia-associated monocytosis and give rise to macrophages in atheromata. J Clin Invest 2007, 117(1):195-205.

61. Swirski FK, Weissleder R, Pittet MJ: Heterogeneous in vivo behavior of monocyte subsets in atherosclerosis. Arterioscler Thromb Vasc Biol 2009, 29(10):1424-32. 
62. Auffray C, Sieweke MH, Geissmann F: Blood monocytes: development, heterogeneity, and relationship with dendritic cells. Annu Rev Immunol 2009, 27:669-92.

63. Geissmann F, Gordon S, Hume DA, Mowat AM, Randolph GJ: Unravelling mononuclear phagocyte heterogeneity. Nat Rev Immunol 2010, 10(6):453-60

64. Geissmann F, Manz MG, Jung S, Sieweke MH, Merad M, Ley K: Development of monocytes, macrophages, and dendritic cells. Science 2010, 327(5966):656-61.

65. Nahrendorf M, Swirski FK, Aikawa E, Stangenberg L, Wurdinger T, Figueiredo $J$, Libby P, Weissleder R, Pittet MJ: The healing myocardium sequentially mobilizes two monocyte subsets with divergent and complementary functions. J Exp Med 2007, 204(12):3037-47.

66. Saederup N, Chan L, Lira SA, Charo IF: Fractalkine deficiency markedly reduces macrophage accumulation and atherosclerotic lesion formation in CCR2-/- mice: evidence for independent chemokine functions in atherogenesis. Circulation 2008, 117(13):1642-8.

67. Combadiere C, Potteaux S, Gao JL, Esposito B, Casanova S, Lee EJ, Debre P, Tedgui A, Murphy PM, Mallat Z: Decreased atherosclerotic lesion formation in CX3CR1/apolipoprotein E double knockout mice. Circulation 2003, 107(7):1009-16

68. Lesnik P, Haskell CA, Charo IF: Decreased atherosclerosis in CX3CR1-/mice reveals a role for fractalkine in atherogenesis. J Clin Invest 2003, 111(3):333-40

69. Teupser D, Pavlides S, Tan M, Gutierrez-Ramos JC, Kolbeck R, Breslow JL: Major reduction of atherosclerosis in fractalkine (CX3CL1)-deficient mice is at the brachiocephalic artery, not the aortic root. Proc Natl Acad Sci USA 2004, 101(51):17795-800.

70. Boring L, Gosling J, Cleary M, Charo IF: Decreased lesion formation in CCR2-/- mice reveals a role for chemokines in the initiation of atherosclerosis. Nature 1998, 394(6696):894-7.

71. Dawson TC, Kuziel WA, Osahar TA, Maeda N: Absence of CC chemokine receptor-2 reduces atherosclerosis in apolipoprotein E-deficient mice. Atherosclerosis 1999, 143(1):205-11.

72. Kuziel WA, Dawson TC, Quinones M, Garavito E, Chenaux G, Ahuja SS, RL Reddick, Maeda N: CCR5 deficiency is not protective in the early stages of atherogenesis in apoE knockout mice. Atherosclerosis 2003, 167(1):25-32.

73. Zernecke A, Liehn EA, Gao JL, Kuziel WA, Murphy PM, Weber C: Deficiency in CCR5 but not CCR1 protects against neointima formation in atherosclerosisprone mice: involvement of IL-10. Blood 2006, 107(11):4240-3.

74. Combadiere C, Potteaux S, Rodero M, Simon T, Pezard A, Esposito B, Merval R, Proudfoot A, Tedgui A, Mallat Z: Combined inhibition of CCL2, CX3CR1, and CCR5 abrogates Ly6C(hi) and Ly6C(lo) monocytosis and almost abolishes atherosclerosis in hypercholesterolemic mice. Circulation 2008, 117(13):1649-57.

75. Wildgruber M, Lee H, Chudnovskiy A, Yoon TJ, Etzrodt M, Pittet MJ, Nahrendorf M, Croce K, Libby P, Weissleder R, Swirski FK: Monocyte subset dynamics in human atherosclerosis can be profiled with magnetic nanosensors. Plos One 2009, 4(5):e5663.

76. Schlitt A, Heine GH, Blankenberg S, Espinola-Klein C, Dopheide JF, Bickel C, Lackner KJ, Iz M, Meyer J, Darius H, Rupprecht HJ: CD14+CD16+ monocytes in coronary artery disease and their relationship to serum TNF-alpha levels. Thromb Haemost 2004, 92(2):419-24.

77. Schirmer SH, Fledderus JO, van der Laan AM, van der Pouw-Kraan TC, Moerland PD, Volger OL, Baggen JM, Bohm M, Piek JJ, Horrevoets AJ, van Royen N: Suppression of inflammatory signaling in monocytes from patients with coronary artery disease. J Mol Cell Cardiol 2009, 46(2):177-85.

78. Merino A, Buendia P, Martin-Malo A, Aljama P, Ramirez R, Carracedo J: Senescent CD14+CD16+ Monocytes Exhibit Proinflammatory and Proatherosclerotic Activity. J Immunol 2011, 186(3):1809-15.

79. Kuwana M, Okazaki Y, Kodama H, Izumi K, Yasuoka H, Ogawa Y, Kawakami $Y$, Ikeda $Y$ : Human circulating CD14+ monocytes as a source of progenitors that exhibit mesenchymal cell differentiation. J Leukoc Biol 2003, 74(5):833-45

80. Kamari Y, Shaish A, Shemesh S, Vax E, Grosskopf I, Dotan S, White M, Voronov E, Dinarello CA, Apte RN, Harats D: Reduced atherosclerosis and inflammatory cytokines in apolipoprotein-E-deficient mice lacking bone marrow-derived interleukin-1alpha. Biochem Biophys Res Commun 2011, 405(2):197-203.
81. Hamilton JA: Rheumatoid arthritis: opposing actions of haemopoietic growth factors and slow-acting anti-rheumatic drugs. Lancet 1993, 342(8870):536-9.

82. Hamilton JA: Colony-stimulating factors in inflammation and autoimmunity. Nat Rev Immunol 2008, 8(7):533-44.

83. Hashimoto S, Suzuki T, Dong HY, Yamazaki N, Matsushima K: Serial analysis of gene expression in human monocytes and macrophages. Blood 1999, 94(3):837-44.

84. Smith JD, Trogan E, Ginsberg M, Grigaux C, Tian J, Miyata M: Decreased atherosclerosis in mice deficient in both macrophage colony-stimulating factor (op) and apolipoprotein E. Proc Natl Acad Sci USA 1995, 92(18):8264-8

85. Stojakovic M, Krzesz R, Wagner AH, Hecker M: CD154-stimulated GM-CSF release by vascular smooth muscle cells elicits monocyte activation-role in atherogenesis. J Mol Med 2007, 85(11):1229-38.

86. Haghighat A, Weiss D, Whalin MK, Cowan DP, Taylor WR: Granulocyte colony-stimulating factor and granulocyte macrophage colonystimulating factor exacerbate atherosclerosis in apolipoprotein $\mathrm{E}$ deficient mice. Circulation 2007, 115(15):2049-54.

87. Zhu SN, Chen M, Jongstra-Bilen J, Cybulsky MI: GM-CSF regulates intimal cell proliferation in nascent atherosclerotic lesions. J Exp Med 2009, 206(10):2141-9.

88. MCLaren JE, Ramji DP: Interferon gamma: a master regulator of atherosclerosis. Cytokine Growth Factor Rev 2009, 20(2):125-35.

89. Gupta S, Pablo AM, Jiang X, Wang N, Tall AR, Schindler C: IFN-gamma potentiates atherosclerosis in ApoE knock-out mice. J Clin Invest 1997 99(11):2752-61.

90. Raisanen-Sokolowski A, Glysing-Jensen T, Koglin J, Russell ME: Reduced transplant arteriosclerosis in murine cardiac allografts placed in interferon-gamma knockout recipients. Am J Pathol 1998, 152(2):359-65.

91. Loke P, Nair MG, Parkinson J, Guiliano D, Blaxter M, Allen JE: IL-4 dependent alternatively-activated macrophages have a distinctive in vivo gene expression phenotype. BMC Immunol 2002, 3:7.

92. Tabas I: Macrophage death and defective inflammation resolution in atherosclerosis. Nat Rev Immunol 2010, 10(1):36-46.

93. Kreider T, Anthony RM, Urban JF Jr, Gause WC: Alternatively activated macrophages in helminth infections. Curr Opin Immunol 2007, 19(4):448-53

94. Cordeiro-da-Silva A, Tavares J, Araujo N, Cerqueira F, Tomas A, Kong Thoo Lin $\mathrm{P}$, Ouaissi A: Immunological alterations induced by polyamine derivatives on murine splenocytes and human mononuclear cells. Int Immunopharmacol 2004, 4(4):547-56.

95. Gerber JS, Mosser DM: Reversing lipopolysaccharide toxicity by ligating the macrophage Fc gamma receptors. J Immunol 2001, 166(11):6861-8.

96. Fadok VA, Bratton DL, Konowal A, Freed PW, Westcott JY, Henson PM: Macrophages that have ingested apoptotic cells in vitro inhibit proinflammatory cytokine production through autocrine/paracrine mechanisms involving TGF-beta, PGE2, and PAF. J Clin Invest 1998, 101(4):890-8

97. Sternberg EM: Neural regulation of innate immunity: a coordinated nonspecific host response to pathogens. Nat Rev Immunol 2006 6(4):318-28.

98. Liu Y, Cousin JM, Hughes J, Van Damme J, Seckl JR, Haslett C, Dransfield I, Savill J, Rossi AG: Glucocorticoids promote nonphlogistic phagocytosis of apoptotic leukocytes. J Immunol 1999, 162(6):3639-46.

99. Mackaness GB: The Immunological Basis of Acquired Cellular Resistance. J Exp Med 1964, 120:105-20.

100. Yan ZQ, Hansson GK: Innate immunity, macrophage activation, and atherosclerosis. Immunol Rev 2007, 219:187-203.

101. Medzhitov R: Toll-like receptors and innate immunity. Nat Rev Immunol 2001, 1(2):135-45.

102. Medzhitov R, Preston-Hurlburt $P$, Janeway CA Jr: A human homologue of the Drosophila Toll protein signals activation of adaptive immunity. Nature 1997, 388(6640):394-7.

103. Kim TW, Febbraio M, Robinet P, Dugar B, Greene D, Cerny A, Latz E, Gilmour R, Staschke K, Chisolm G, Fox PL, Dicorleto PE, Smith JD, Li X: The Critical Role of IL-1 Receptor-Associated Kinase 4-Mediated NF\{kappa\}B Activation in Modified Low-Density Lipoprotein-Induced Inflammatory Gene Expression and Atherosclerosis. J Immunol 2011, 186(5):2871-80. 
104. Wright SD, Ramos RA, Tobias PS, Ulevitch RJ, Mathison JC: CD14, a receptor for complexes of lipopolysaccharide (LPS) and LPS binding protein. Science 1990, 249(4975):1431-3.

105. Tobias PS, Soldau K, Kline L, Lee JD, Kato K, Martin TP, Ulevitch RJ: Crosslinking of lipopolysaccharide (LPS) to CD14 on THP-1 cells mediated by LPS-binding protein. J Immunol 1993, 150(7):3011-21.

106. Hoebe K, Georgel P, Rutschmann S, Du X, Mudd S, Crozat K, Sovath S, Shamel L, Hartung T, Zähringer U, Beutler B: CD36 is a sensor of diacylglycerides. Nature 2005, 433(7025):523-7.

107. Miller YI, Choi SH, Wiesner P, Fang L, Harkewicz R, Hartvigsen K, Boullier A, Gonen A, Diehl CJ, Que X, Montano E, Shaw PX, Tsimikas S, Binder CJ, Witztum JL: Oxidation-specific epitopes are danger-associated molecular patterns recognized by pattern recognition receptors of innate immunity. Circ Res 2011, 108(2):235-48.

108. Li M, Carpio DF, Zheng Y, Bruzzo P, Singh V, Ouaaz F, Medzhitov RM, Beg AA: An essential role of the NF-kappa B/Toll-like receptor pathway in induction of inflammatory and tissue-repair gene expression by necrotic cells. J Immunol 2001, 166(12):7128-35.

109. Kawakami A, Osaka M, Aikawa M, Uematsu S, Akira S, Libby P, Shimokado K, Sacks FM, Yoshida M: Toll-like receptor 2 mediates apolipoprotein CIIIinduced monocyte activation. Circ Res 2008, 103(12):1402-9.

110. Cheng N, He R, Tian J, Ye P, Ye R: Cutting edge: TLR2 is a functional receptor for acute-phase serum amyloid A. J Immunol 2008, 181(1):22-6.

111. Kim S, Takahashi H, Lin WW, Descargues P, Grivennikov S, Kim Y, Luo JL, Karin M: Carcinoma-produced factors activate myeloid cells through TLR2 to stimulate metastasis. Nature 2009, 457(7225):102-6.

112. Seimon TA, Nadolski MJ, Liao X, Magallon J, Nguyen M, Feric NT, Koschinsky ML, Harkewicz R, Witztum JL, Tsimikas S, Golenbock D, Moore KJ, Tabas I: Atherogenic lipids and lipoproteins trigger CD36-TLR2dependent apoptosis in macrophages undergoing endoplasmic reticulum stress. Cell Metab 2010, 12(5):467-82.

113. Scheibner K, Lutz M, Boodoo S, Fenton M, Powell J, Horton M: Hyaluronan fragments act as an endogenous danger signal by engaging TLR2. J Immunol 2006, 177(2):1272-81.

114. Schaefer L, Babelova A, Kiss E, Hausser HJ, Baliova M, Krzyzankova M, Marsche G, Young MF, Mihalik D, Gotte M, Malle E, Schaefer RM, Grone HJ: The matrix component biglycan is proinflammatory and signals through Toll-like receptors 4 and 2 in macrophages. J Clin Invest 2005, 115(8):2223-33.

115. Holvoet $P$, Davey PC, De Keyzer D, Doukouré M, Deridder E, BochatonPiallat M-L, Gabbiani G, Beaufort E, Bishay K, Andrieux N, Benhabilès N, Marguerie G: Oxidized low-density lipoprotein correlates positively with toll-like receptor 2 and interferon regulatory factor- 1 and inversely with superoxide dismutase-1 expression: studies in hypercholesterolemic swine and THP-1 cells. Arterioscler Thromb Vasc Biol 2006, 26(7):1558-65.

116. Xu XH, Shah PK, Faure E, Equils O, Thomas L, Fishbein MC, Luthringer D, Xu XP, Rajavashisth TB, Yano J, Kaul S, Arditi M: Toll-like receptor-4 is expressed by macrophages in murine and human lipid-rich atherosclerotic plaques and upregulated by oxidized LDL. Circulation 2001, 104(25):3103-8

117. Asea A, Rehli M, Kabingu E, Boch JA, Bare O, Auron PE, Stevenson MA, Calderwood SK: Novel signal transduction pathway utilized by extracellular HSP70: role of toll-like receptor (TLR) 2 and TLR4. J Biol Chem 2002, 277(17):15028-34.

118. Guillot L, Balloy V, McCormack FX, Golenbock DT, Chignard M, Si-Tahar M: Cutting edge: the immunostimulatory activity of the lung surfactant protein-A involves Toll-like receptor 4. J Immunol 2002, 168(12):5989-92.

119. Midwood K, Sacre S, Piccinini AM, Inglis J, Trebaul A, Chan E, Drexler S, Sofat N, Kashiwagi M, Orend G, Brennan F, Foxwell B: Tenascin-C is an endogenous activator of Toll-like receptor 4 that is essential for maintaining inflammation in arthritic joint disease. Nat Med 2009, 15(7):774-80.

120. Smiley ST, King JA, Hancock WW: Fibrinogen stimulates macrophage chemokine secretion through toll-like receptor 4. J Immunol 2001, 167(5):2887-94.

121. Okamura Y, Watari M, Jerud ES, Young DW, Ishizaka ST, Rose J, Chow JC, Strauss JF: The extra domain A of fibronectin activates Toll-like receptor 4. J Biol Chem 2001, 276(13):10229-33.

122. Kodaira Y, Nair SK, Wrenshall LE, Gilboa E, Platt JL: Phenotypic and functional maturation of dendritic cells mediated by heparan sulfate. $J$ Immunol 2000, 165(3):1599-604.
123. Biragyn A, Ruffini PA, Leifer CA, Klyushnenkova E, Shakhov A, Chertov O, Shirakawa AK, Farber JM, Segal DM, Oppenheim JJ, Kwak LW: Toll-like receptor 4-dependent activation of dendritic cells by beta-defensin 2 . Science 2002, 298(5595):1025-9.

124. Cole JE, Navin TJ, Cross AJ, Goddard ME, Alexopoulou L, Mitra AT, Davies AH, Flavell RA, Feldmann M, Monaco C: From the Cover: Unexpected protective role for Toll-like receptor 3 in the arterial wall. Proc Natl Acad Sci USA 2011, 108(6):2372-7.

125. H. Ni, Capodici J, Lamphier M, Weissman D: mRNA is an endogenous ligand for Toll-like receptor 3. J Biol Chem 2004, 279(13):12542-50.

126. Boule MW, Broughton C, Mackay F, Akira S, Marshak-Rothstein A, Rifkin IR: Toll-like receptor 9-dependent and -independent dendritic cell activation by chromatin-immunoglobulin G complexes. J Exp Med 2004, 199(12):1631-40.

127. Leadbetter E, Rifkin I, Hohlbaum A, Beaudette B, Shlomchik M, MarshakRothstein A: Chromatin-lgG complexes activate $B$ cells by dual engagement of IgM and Toll-like receptors. Nature 2002, 416(6881):603-7.

128. Stewart CR, Stuart LM, Wilkinson K, van Gils JM, Deng J, Halle A, Rayner KJ, Boyer L, Zhong R, Frazier WA, Lacy-Hulbert A, El Khoury J, Golenbock DT, Moore KJ: CD36 ligands promote sterile inflammation through assembly of a Toll-like receptor 4 and 6 heterodimer. Nat Immunol 2010, 11(2):155-61.

129. Walton KA, Hsieh X, Gharavi N, Wang S, Wang G, Yeh M, Cole AL, Berliner JA: Receptors involved in the oxidized 1-palmitoyl-2arachidonoyl-sn-glycero-3-phosphorylcholine-mediated synthesis of interleukin-8. A role for Toll-like receptor 4 and a glycosylphosphatidylinositol-anchored protein. J Biol Chem 2003, 278(32):29661-6.

130. Walton KA, Cole AL, Yeh M, Subbanagounder G, Krutzik SR, Modlin RL, Lucas RM, Nakai J, Smart EJ, Vora DK, Berliner JA: Specific phospholipid oxidation products inhibit ligand activation of toll-like receptors 4 and 2 . Arterioscler Thromb Vasc Biol 2003, 23(7):1197-203.

131. Bae YS, Lee JH, Choi SH, Kim S, Almazan F, Witztum JL, Miller Yl: Macrophages generate reactive oxygen species in response to minimally oxidized low-density lipoprotein: toll-like receptor 4- and spleen tyrosine kinase-dependent activation of NADPH oxidase 2. Circ Res 2009, 104(2):210-8, 21p following 218.

132. Edfeldt K, Swedenborg J, Hansson G, Yan Z: Expression of toll-like receptors in human atherosclerotic lesions: a possible pathway for plaque activation. Circulation 2002, 105(10):1158-61.

133. Schoneveld A, Hoefer I, Sluijter J, Laman J, de Kleijn D, Pasterkamp G: Atherosclerotic lesion development and Toll like receptor 2 and 4 responsiveness. Atherosclerosis 2008, 197(1):95-104.

134. Geng H, Lu H, Zhang L, Zhang H, Zhou L, Wang H, Zhong R: Increased expression of Toll like receptor 4 on peripheral-blood mononuclear cells in patients with coronary arteriosclerosis disease. Clin Exp Immunol 2006, 143(2):269-73.

135. Methe H, Kim J, Kofler S, Weis M, Nabauer M, Koglin J: Expansion of circulating Toll-like receptor 4-positive monocytes in patients with acute coronary syndrome. Circulation 2005, 111(20):2654-61.

136. Shiraki R, Inoue N, Kobayashi S, Ejiri J, Otsui K, Honjo T, Takahashi M, Hirata K, Yokoyama M, Kawashima S: Toll-like receptor 4 expressions on peripheral blood monocytes were enhanced in coronary artery disease even in patients with low C-reactive protein. Life Sci 2006, 80(1):59-66.

137. Kuwahata S, Fujita S, Orihara K, Hamasaki S, Oba R, Hirai H, Nagata K, Ishida S, Kataoka T, Oketani N, Ichiki H, Iriki Y, Saihara K, Okui H, Ninomiya Y, Tei C: High expression level of Toll-like receptor 2 on monocytes is an important risk factor for arteriosclerotic disease. Atherosclerosis 2009

138. Ashida K, Miyazaki K, Takayama E, Tsujimoto H, Ayaori M, Yakushiji T, Iwamoto N, Yonemura A, Isoda K, Mochizuki H, Hiraide H, Kusuhara M, Ohsuzu F: Characterization of the expression of TLR2 (toll-like receptor 2) and TLR4 on circulating monocytes in coronary artery disease. J Atheroscler Thromb 2005, 12(1):53-60.

139. Liuzzo G, Angiolillo DJ, Buffon A, Rizzello V, Colizzi C, Ginnetti F, Biasucci LM, Maseri A: Enhanced response of blood monocytes to in vitro lipopolysaccharide-challenge in patients with recurrent unstable angina. Circulation 2001, 103(18):2236-41.

140. Versteeg D, Hoefer IE, Schoneveld AH, De Kleijn DPV, Busser E, Strijder C, Emons M, Stella PR, Doevendans PA, Pasterkamp G: Monocyte toll-like receptor 2 and 4 responses and expression following percutaneous 
coronary intervention: association with lesion stenosis and fractional flow reserve. Heart 2008, 94(6):770-776.

141. Michelsen KS, Wong MH, Shah PK, Zhang W, Yano J, Doherty TM, Akira S, Rajavashisth TB, Arditi M: Lack of Toll-like receptor 4 or myeloid differentiation factor 88 reduces atherosclerosis and alters plaque phenotype in mice deficient in apolipoprotein E. Proc Natl Acad Sci USA 2004, 101(29):10679-84.

142. Bjorkbacka H, Kunjathoor W, Moore KJ, Koehn S, Ordija CM, Lee MA, Means T, Halmen K, Luster AD, Golenbock DT, Freeman MW: Reduced atherosclerosis in MyD88-null mice links elevated serum cholesterol levels to activation of innate immunity signaling pathways. Nat Med 2004, 10(4):416-21.

143. Monaco C, Gregan SM, Navin TJ, Foxwell BM, Davies AH, Feldmann M: Tolllike receptor-2 mediates inflammation and matrix degradation in human atherosclerosis. Circulation 2009, 120(24):2462-9.

144. Ishida BY, Blanche PJ, Nichols AV, Yashar M, Paigen B: Effects of atherogenic diet consumption on lipoproteins in mouse strains C57BL/6 and C3H. J Lipid Res 1991, 32(4):559-68.

145. Nishina P, Wang J, Toyofuku W, Kuypers F, Ishida B, Paigen B: Atherosclerosis and plasma and liver lipids in nine inbred strains of mice. Lipids 1993, 28(7):599-605.

146. Mullick AE, Tobias PS, Curtiss LK: Modulation of atherosclerosis in mice by Toll-like receptor 2. J Clin Invest 2005, 115(11):3149-56.

147. Madan M, Amar S: Toll-like receptor-2 mediates diet and/or pathogen associated atherosclerosis: proteomic findings. PLOS ONE 2008, 3(9):e3204

148. Liu X, Ukai T, Yumoto H, Davey M, Goswami S, Gibson FC, Genco CA: Tolllike receptor 2 plays a critical role in the progression of atherosclerosis that is independent of dietary lipids. Atherosclerosis 2008, 196(1):146-54.

149. Vink A, Schoneveld AH, van der Meer JJ, van Middelaar BJ, Sluijter JP, Smeets MB, Quax PH, Lim SK, Borst C, Pasterkamp G, de Kleijn DP: In vivo evidence for a role of toll-like receptor 4 in the development of intimal lesions. Circulation 2002, 106(15):1985-90.

150. Schoneveld AH, Oude Nijhuis MM, van Middelaar B, Laman JD, de Kleijn DP, Pasterkamp G: Toll-like receptor 2 stimulation induces intimal hyperplasia and atherosclerotic lesion development. Cardiovasc Res 2005, 66(1):162-9.

151. Shinohara M, Hirata K, Yamashita T, Takaya T, Sasaki N, Shiraki R, Ueyama T, Emoto N, Inoue N, Yokoyama M, Kawashima S: Local overexpression of toll-like receptors at the vessel wall induces atherosclerotic lesion formation: synergism of TLR2 and TLR4. Arterioscler Thromb Vasc Biol 2007, 27(11):2384-91.

152. Shi W, Wang NJ, Shih DM, Sun VZ, Wang X, Lusis AJ: Determinants of atherosclerosis susceptibility in the $\mathrm{C} 3 \mathrm{H}$ and $\mathrm{C} 57 \mathrm{BL} / 6$ mouse model: evidence for involvement of endothelial cells but not blood cells or cholesterol metabolism. Circ Res 2000, 86(10):1078-84.

153. Funk J, Feingold K, Moser A, Grunfeld C: Lipopolysaccharide stimulation of RAW 264.7 macrophages induces lipid accumulation and foam cell formation. Atherosclerosis 1993, 98(1):67-82.

154. Lee JG, Lim EJ, Park DW, Lee SH, Kim JR, Baek SH: A combination of Lox-1 and Nox1 regulates TLR9-mediated foam cell formation. Cell Signal 2008, 20(12):2266-75.

155. Oiknine J, Aviram M: Increased susceptibility to activation and increased uptake of low density lipoprotein by cholesterol-loaded macrophages. Arterioscler Thromb 1992, 12(6):745-53.

156. S Choi, Harkewicz R, Lee J, Boullier A, Almazan F, Li A, Witztum J, Bae Y, Miller Y: Lipoprotein accumulation in macrophages via toll-like receptor4-dependent fluid phase uptake. Circ Res 2009, 104(12):1355-63.

157. Bar-Or A, Nuttall RK, Duddy M, Alter A, Kim HJ, Ifergan I, Pennington CJ, Bourgoin P, Edwards DR, Yong WW: Analyses of all matrix metalloproteinase members in leukocytes emphasize monocytes as major inflammatory mediators in multiple sclerosis. Brain 2003, 126(Pt 12):2738-49.

158. Welgus HG, Campbell EJ, Cury JD, Eisen AZ, Senior RM, Wilhelm SM, Goldberg Gl: Neutral metalloproteinases produced by human mononuclear phagocytes. Enzyme profile, regulation, and expression during cellular development. J Clin Invest 1990, 86(5):1496-502.

159. Ardans JA, Economou AP, Martinson JM Jr, Zhou M, Wahl LM: Oxidized low-density and high-density lipoproteins regulate the production of matrix metalloproteinase- 1 and -9 by activated monocytes. J Leukoc Biol 2002, 71(6):1012-8.

160. Saren P, Welgus HG, Kovanen PT: TNF-alpha and IL-1 beta selectively induce expression of $92-\mathrm{kDa}$ gelatinase by human macrophages. J Immunol 1996, 157(9):4159-65.
161. Herman MP, Sukhova GK, Libby P, Gerdes N, Tang N, Horton DB, Kilbride M, Breitbart RE, Chun M, Schonbeck U: Expression of neutrophil collagenase (matrix metalloproteinase-8) in human atheroma: a novel collagenolytic pathway suggested by transcriptional profiling. Circulation 2001, 104(16):1899-904.

162. Shapiro SD, Campbell EJ, Kobayashi DK, Welgus HG: Immune modulation of metalloproteinase production in human macrophages. Selective pretranslational suppression of interstitial collagenase and stromelysin biosynthesis by interferon-gamma. J Clin Invest 1990, 86(4):1204-10.

163. Fabunmi RP, Sukhova GK, Sugiyama S, Libby P: Expression of tissue inhibitor of metalloproteinases-3 in human atheroma and regulation in lesion-associated cells: a potential protective mechanism in plaque stability. Circ Res 1998, 83(3):270-8.

164. Guarda G, Braun M, Staehli F, Tardivel A, Mattmann C, Forster I, Farlik M, Decker T, Du Pasquier RA, Romero P, Tschopp J: Type I interferon inhibits interleukin-1 production and inflammasome activation. Immunity 2011, 34(2):213-23.

165. Zhang LN, Velichko S, Vincelette J, Fitch RM, Vergona R, Sullivan ME, Croze E, Wang YX: Interferon-beta attenuates angiotensin II-accelerated atherosclerosis and vascular remodeling in apolipoprotein $\mathrm{E}$ deficient mice. Atherosclerosis 2008, 197(1):204-11

166. Goossens P, Gijbels MJ, Zernecke A, Eijgelaar W, Vergouwe MN, van der Made I, Vanderlocht J, Beckers L, Buurman WA, Daemen MJ, Kalinke U, Weber C, Lutgens E, de Winther MP: Myeloid type I interferon signaling promotes atherosclerosis by stimulating macrophage recruitment to lesions. Cell Metab 2010, 12(2):142-53.

167. Zimmer S, Steinmetz M, Asdonk T, Motz I, Coch C, Hartmann E, Barchet W, Wassmann S, Hartmann G, Nickenig G: Activation of Endothelial Toll-Like Receptor 3 Impairs Endothelial Function. Circ Res 2011.

168. Koga N, Suzuki J, Kosuge H, Haraguchi G, Onai Y, Futamatsu H, Maejima Y, Gotoh R, Saiki H, Tsushima F, Azuma M, Isobe M: Blockade of the interaction between PD-1 and PD-L1 accelerates graft arterial disease in cardiac allografts. Arterioscler Thromb Vasc Biol 2004, 24(11):2057-62.

169. Groschel S, Piggott KD, Vaglio A, Ma-Krupa W, Singh K, Goronzy JJ, Weyand CM: TLR-mediated induction of negative regulatory ligands on dendritic cells. J Mol Med 2008, 86(4):443-55.

170. Bsibsi M, Bajramovic JJ, Vogt MH, van Duijvenvoorden E, Baghat A, PersoonDeen C, Tielen F, Verbeek R, Huitinga I, Ryffel B, Kros A, Gerritsen WH, Amor $S$, van Noort JM: The microtubule regulator stathmin is an endogenous protein agonist for TLR3. J Immunol 2010, 184(12):6929-37.

171. Martinon F, Mayor A, Tschopp J: The inflammasomes: guardians of the body. Annu Rev Immunol 2009, 27:229-65.

172. Wang S, Miura M, Jung YK, Zhu H, Li E, Yuan J: Murine caspase-11, an ICEinteracting protease, is essential for the activation of ICE. Cell 1998, 92(4):501-9.

173. Mariathasan S, Monack DM: Inflammasome adaptors and sensors: intracellular regulators of infection and inflammation. Nat Rev Immunol 2007, 7(1):31-40

174. Burns K, Martinon F, Tschopp J: New insights into the mechanism of IL1beta maturation. Curr Opin Immunol 2003, 15(1):26-30.

175. Yajima N, Takahashi M, Morimoto H, Shiba Y, Takahashi Y, Masumoto J, Ise H, Sagara J, Nakayama J, Taniguchi S, Ikeda U: Critical role of bone marrow apoptosis-associated speck-like protein, an inflammasome adaptor molecule, in neointimal formation after vascular injury in mice. Circulation 2008, 117(24):3079-87.

176. Kirii H, Niwa T, Yamada Y, Wada H, Saito K, Iwakura Y, Asano M, Moriwaki $H$, Seishima M: Lack of interleukin-1 beta decreases the severity of atherosclerosis in ApoE-deficient mice. Arterioscler Thromb Vasc Biol 2003, 23(4):656-60.

177. Elhage R, Jawien J, Rudling M, Ljunggren HG, Takeda K, Akira S, Bayard F, Hansson GK: Reduced atherosclerosis in interleukin-18 deficient apolipoprotein E-knockout mice. Cardiovasc Res 2003, 59(1):234-40

178. Devlin CM, Kuriakose G, Hirsch E, Tabas I: Genetic alterations of IL-1 receptor antagonist in mice affect plasma cholesterol level and foam cell lesion size. Proc Natl Acad Sci USA 2002, 99(9):6280-5.

179. Dewberry R, Holden H, Crossman D, Francis S: Interleukin-1 receptor antagonist expression in human endothelial cells and atherosclerosis. Arterioscler Thromb Vasc Biol 2000, 20(11):2394-400.

180. Ishii N, Matsumura T, Kinoshita H, Fukuda K, Motoshima H, Senokuchi T, Nakao S, Tsutsumi A, Kim-Mitsuyama S, Kawada T, Takeya M, Miyamura N, Nishikawa T, Araki E: Nifedipine induces peroxisome proliferator-activated 
receptor-gamma activation in macrophages and suppresses the progression of atherosclerosis in apolipoprotein E-deficient mice. Arterioscler Thromb Vasc Biol 2010, 30(8):1598-605.

181. Nakaya H, Summers BD, Nicholson AC, Gotto AM Jr, Hajjar DP, Han J: Atherosclerosis in LDLR-knockout mice is inhibited, but not reversed, by the PPARgamma ligand pioglitazone. Am J Pathol 2009, 174(6):2007-14.

182. Chinetti G, Fruchart JC, Staels B: Peroxisome proliferator-activated receptors (PPARs): nuclear receptors at the crossroads between lipid metabolism and inflammation. Inflamm Res 2000, 49(10):497-505.

183. Odegaard Jl, Ricardo-Gonzalez RR, Goforth MH, Morel CR, Subramanian V, Mukundan L, Red Eagle A, Vats D, Brombacher F, Ferrante AW, Chawla A: Macrophage-specific PPARgamma controls alternative activation and improves insulin resistance. Nature 2007, 447(7148):1116-20.

184. Tontonoz P, Nagy L, Alvarez JG, Thomazy VA, Evans RM: PPARgamma promotes monocyte/macrophage differentiation and uptake of oxidized LDL. Cell 1998, 93(2):241-52.

185. Straus DS, Glass CK: Anti-inflammatory actions of PPAR ligands: new insights on cellular and molecular mechanisms. Trends Immunol 2007, 28(12):551-8.

186. Heilbronn LK, Campbell LV: Adipose tissue macrophages, low grade inflammation and insulin resistance in human obesity. Curr Pharm Des 2008, 14(12):1225-30.

187. Coste A, Dubourdeau M, Linas MD, Cassaing S, Lepert JC, Balard P, Chalmeton S, Bernad J, Orfila C, Seguela JP, Pipy B: PPARgamma promotes mannose receptor gene expression in murine macrophages and contributes to the induction of this receptor by IL-13. Immunity 2003, 19(3):329-39.

188. Kim SR, Lee KS, Park HS, Park SJ, Min KH, Jin SM, Lee YC: Involvement of IL10 in peroxisome proliferator-activated receptor gamma-mediated antiinflammatory response in asthma. Mol Pharmacol 2005, 68(6):1568-75.

189. Hetzel M, Walcher D, Grub M, Bach H, Hombach V, Marx N: Inhibition of MMP-9 expression by PPARgamma activators in human bronchial epithelial cells. Thorax 2003, 58(9):778-83.

190. Marx N, Imhof A, Froehlich J, Siam L, Ittner J, Wierse G, Schmidt A, Maerz W, Hombach V, Koenig W: Effect of rosiglitazone treatment on soluble $\mathrm{CD} 40 \mathrm{~L}$ in patients with type 2 diabetes and coronary artery disease. Circulation 2003, 107(15):1954-7.

191. Glatz T, Stock I, Nguyen-Ngoc M, Gohlke P, Herdegen T, Culman J, Zhao Y: Peroxisome-proliferator-activated receptors gamma and peroxisomeproliferator-activated receptors beta/delta and the regulation of interleukin 1 receptor antagonist expression by pioglitazone in ischaemic brain. J Hypertens 2010, 28(7):1488-97.

192. Moulin D, Bianchi A, Boyault S, Sebillaud S, Koufany M, Francois M, Netter P, Jouzeau JY, Terlain B: Rosiglitazone induces interleukin-1 receptor antagonist in interleukin-1 beta-stimulated rat synovial fibroblasts via a peroxisome proliferator-activated receptor beta/delta-dependent mechanism. Arthritis Rheum 2005, 52(3):759-69.

193. Halvorsen B, Heggen E, Ueland T, Smith C, Sandberg WJ, Damas JK, Otterdal K, Tonstad S, Aukrust P: Treatment with the PPARgamma agonist rosiglitazone downregulates interleukin-1 receptor antagonist in individuals with metabolic syndrome. Eur J Endocrinol 2010, 162(2):267-73.

194. Fernandez AZ: Peroxisome proliferator-activated receptors in the modulation of the immune/inflammatory response in atherosclerosis. PPAR Res 2008, 2008:285842.

195. Ziegler-Heitbrock L: The CD14+CD16+ blood monocytes: their role in infection and inflammation. J Leukoc Biol 2007, 81(3):584-92.

196. Yona S, Jung S: Monocytes: subsets, origins, fates and functions. Curr Opin Hematol 2010, 17(1):53-9.

doi:10.1186/1476-9255-8-9

Cite this article as: Shalhoub et al:: Innate immunity and monocytemacrophage activation in atherosclerosis. Journal of Inflammation 2011 8:9.

\section{Submit your next manuscript to BioMed Central and take full advantage of:}

- Convenient online submission

- Thorough peer review

- No space constraints or color figure charges

- Immediate publication on acceptance

- Inclusion in PubMed, CAS, Scopus and Google Scholar

- Research which is freely available for redistribution

Submit your manuscript at www.biomedcentral.com/submit
Biomed Central 